Int. J. Dev. Biol. 59: 289-301 (2015)

doi: $10.1387 / \mathrm{ijdb} .150209 \mathrm{sw}$

\title{
Inhibition of SOCE disrupts cytokinesis in zebrafish embryos via inhibition of cleavage furrow deepening
}

\author{
CHING M. CHAN ${ }^{1, \#,}$, YIYUN CHEN ${ }^{1, \#,}$, TIN S. HUNG ${ }^{1}$, ANDREW L. MILLER ${ }^{1,2}$, ALAN M. SHIPLEY ${ }^{3}$ \\ and SARAH E. WEBB*,1 \\ ${ }^{1}$ Division of Life Science \& State Key Laboratory of Molecular Neuroscience, HKUST, Clear Water Bay, Hong Kong, \\ PRC, ${ }^{2}$ MBL, Woods Hole, MA, USA and ${ }^{3}$ Applicable Electronics LLC, New Haven, CT, USA
}

\begin{abstract}
During the first few cell division cycles in zebrafish, distinct $\mathrm{Ca}^{2+}$ transients are localized to the early embryonic cleavage furrows, where they accompany (and are required for) furrow positioning, propagation, deepening and apposition. It has previously been shown that the endoplasmic reticulum (ER) acts as the primary store for generating these $\mathrm{Ca}^{2+}$ transients via release through inositol 1,4,5-trisphosphate receptors ( $\left(\mathrm{P}_{3} \mathrm{Rs}\right)$. We hypothesised that maintaining the elevated levels of intracellular $\mathrm{Ca}^{2+}$ required for deepening and apposition of the cleavage furrows in these large eggs might result in the depletion of the available ER $\mathrm{Ca}^{2+}$ store, thus the role of store-operated $\mathrm{Ca}^{2+}$ entry (SOCE) was examined. Newly fertilized, dechorionated embryos were incubated with various SOCE inhibitors, starting just prior to the onset of the first cell division cycle. The effect of these inhibitors on mitosis, furrow positioning, propagation, deepening and apposition, and the generation of the cytokinetic $\mathrm{Ca}^{2+}$ transients was determined. Treatment with 2-APB or SKF 96365 had no major effect on mitosis, furrow positioning or propagation, but inhibited furrow deepening resulting in regression of the cleavage furrow. Both of these inhibitors also blocked the furrowing $\mathrm{Ca}^{2+}$ transient, with SKF 96365 having a more profound inhibitory effect than 2-APB. In zebrafish, SOCE does not appear to be required for mitosis or the early stages of cytokinesis during the early embryonic cell division cycles, but it does appear to be essential for maintaining the elevated levels of $\left[\mathrm{Ca}^{2+}\right]_{i}$ for the extended periods that are required during furrow deepening and daughter cell apposition.
\end{abstract}

KEY WORDS: aequorin, cytokinesis, Ca ${ }^{2+}$ signalling, store-operated $\mathrm{Ca}^{2+}$ entry, zebrafish embryo

\section{Introduction}

It has been reported that during cytokinesis, distinct $\mathrm{Ca}^{2+}$ transients are localized to the early embryonic cleavage furrows of a variety of Cypriniformes species, including medaka (Oryzias latipes; Fluck et al., 1991; Webb et al., 2011), zebrafish (Danio rerio; Chang and Meng, 1995; Webb et al., 1997; Créton et al., 1998; Chang and Lu., 2000; Webb and Miller, 2007), rosy barb (Puntius conchonious; Webb and Miller, 2007), and mummichog (Fundulus heteroclitus; Webb and Miller, 2007). In these large meroblastically cleaving embryos, cytokinesis is divided into a number of sequential steps; furrow positioning, propagation, deepening and apposition, and each step is accompanied by its own distinctive $\mathrm{Ca}^{2+}$ transient (Webb et al., 1997; Lee et al., 2003; 2006). In spite of the general consensus that these $\mathrm{Ca}^{2+}$ transients are required for cytokinesis, the $\mathrm{Ca}^{2+}$ source responsible for generating the deepening and ap- position transients as well as the precise molecular targets and mechanisms of action of all of the transients remain elusive. In this project, we aimed to address the first of these points.

Consideration of the duration and magnitude of each of the cytokinetic $\mathrm{Ca}^{2+}$ transients was crucial to our investigation of the potential sources of $\mathrm{Ca}^{2+}$ contributing to this process. We also had to take into account which particular $\left[\mathrm{Ca}^{2+}\right]_{\mathrm{i}}$ regulatory elements might be encountered between the $\mathrm{Ca}^{2+}$ source and the furrow

\footnotetext{
Abbreviations used in this paper: 2-APB, 2-aminoethoxyldiphenyl borate; BTP-2, $\mathcal{N}$-[4-[3,5-Bis(trifluoromethyl)-1 $H$-pyrazol-1-yl]phenyl]-4-methyl-1,2,3-thiadiazole5-carboxamide; DMSO, dimethyl sulphoxide; ER, endoplasmic reticulum; IP3R, inositol 1,4,5-trisphosphate receptor; mpf, minutes post fertilization; MLCK, myosin light chain kinase; MT, microtubule; SOCE, store-operated $\mathrm{Ca}^{2+}$ entry; SOC, store-operated channel; STIM1, Stromal interaction molecule 1; TRPG1, Transient receptor potential channel 1 .
}

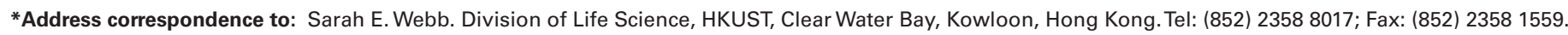
E-mail: barnie@ust.hk - web: http://ihome.ust.hk/ aequorin

\#These authors contributed equally to this paper.

Accepted: 20 July 2015.

ISSN: Online 1696-3547, Print 0214-6282 
cytosol. The furrow positioning $\mathrm{Ca}^{2+}$ transient is the briefest of the four signals, lasting $\sim 60 \mathrm{~s}$ (at $28^{\circ} \mathrm{C}$; Lee et al., 2006), before it extends and develops into the furrow propagation signal. The latter takes the form of two slow $(\sim 0.5 \mu \mathrm{m} / \mathrm{sec})$ linear $\mathrm{Ca}^{2+}$ waves that extend from the lateral extremities of the furrow positioning arc out to the edges of the blastoderm (Webb et al., 1997), and lasts for $\sim 120 \mathrm{~s}$ (Lee et al., 2006). The furrow deepening $\mathrm{Ca}^{2+}$ signal, on the other hand, is the longest lasting signal, and once again takes the form of a pair of slow $\mathrm{Ca}^{2+}$ waves that travel (at $\sim 0.5 \mu \mathrm{m} / \mathrm{sec}$ ) from the apex of the blastodisc (i.e., the site of the furrow positioning signal) out towards its edges along the same tracks as the propagation signal, while also ingressing down through the blastoderm (at $\sim 0.1 \mu \mathrm{m} / \mathrm{sec}$ ) to meet the rising yolk cell that constitutes the blastoderm floor (Webb et al., 1997; Lee et al., 2003; Webb et al., 2011). It takes 500 s from the appearance of the furrow deepening signal that accompanies the initiation of furrow ingression, until the leading edge of the furrow deepening signal reaches the top of the yolk cell (Webb et al., 1997). This process effectively divides the blastoderm, forming two daughter cells each with its own nucleus. Early embryonic cell division in zebrafish is then followed by a process of cleavage furrow apposition, which keeps the embryo as a compact entity during early development (Jesuthasan, 1998). This process has been termed cleavage furrow apposition or zipping (Fluck et al., 1991), and the $\mathrm{Ca}^{2+}$ signal that accompanies this process lasts for $200 \mathrm{~s}$ (Webb et al., 1997). In terms of the magnitude of the intracellular $\mathrm{Ca}^{2+}$ rise during the cytokinetic transients, an approximate five-fold increase above resting levels (i.e., from $~ 100$ $\mathrm{nM}$ to $\sim 500 \mathrm{nM}$ ) has been reported (Webb et al., 1997). Thus, for deepening and apposition to be completed it takes $\sim 700$ s, (i.e., $\sim 12 \mathrm{~min}$ ) of sustained elevated [ $\left.\mathrm{Ca}^{2+}\right]$ in the localized regions of the blastoderm involved in the cytokinetic process. When these timings are added to the $\sim 60$-sec and $\sim 120$-sec durations of the positioning and propagation signals, respectively, it comes to a total of $\sim 15$ min for cytokinesis to be complete (at $28^{\circ} \mathrm{C}$ ).

The goal of this report, therefore, was to investigate which members of the cell's $\mathrm{Ca}^{2+}$ signaling toolkit (Berridge et al., 2000) might be involved in generating and maintaining a sustained intracellular $\mathrm{Ca}^{2+}$ signal for a period of $\sim 12$ min during furrow deepening and apposition. To date, it has been generally accepted that the endoplasmic reticulum (ER) acts as the primary $\mathrm{Ca}^{2+}$ store for generating all of the cytoplasmic $\mathrm{Ca}^{2+}$ transients in zebrafish embryos via release mainly through $\mathrm{IP}_{3} \mathrm{Rs}$ (Créton et al., 1998; Chang and Meng, 1995; Webb et al., 1997; Lee et al., 2003, 2006). We hypothesized that such a sustained $\mathrm{Ca}^{2+}$ release was likely to deplete the ER $\mathrm{Ca}^{2+}$ store before cytokinesis was completed. Thus, $\mathrm{Ca}^{2+}$ toolkit elements participating in store-operated calcium entry (SOCE) to refill the ER were obvious additional candidates for investigation.

SOCE is a process where a decrease in $\mathrm{ER} \mathrm{Ca}^{2+}$ content (sensed by stromal interaction molecule 1; STIM1) activates $\mathrm{Ca}^{2+}$ entry into the cytoplasm across the plasma membrane (PM) via Orai1, a protein that functions as a
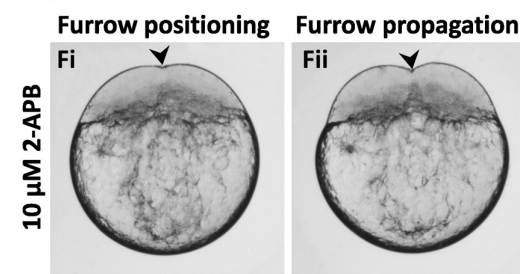

Furrow deepening Fii

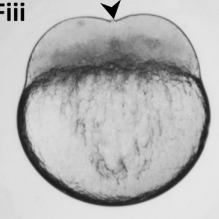

Furrow regression Fiv $\gamma$
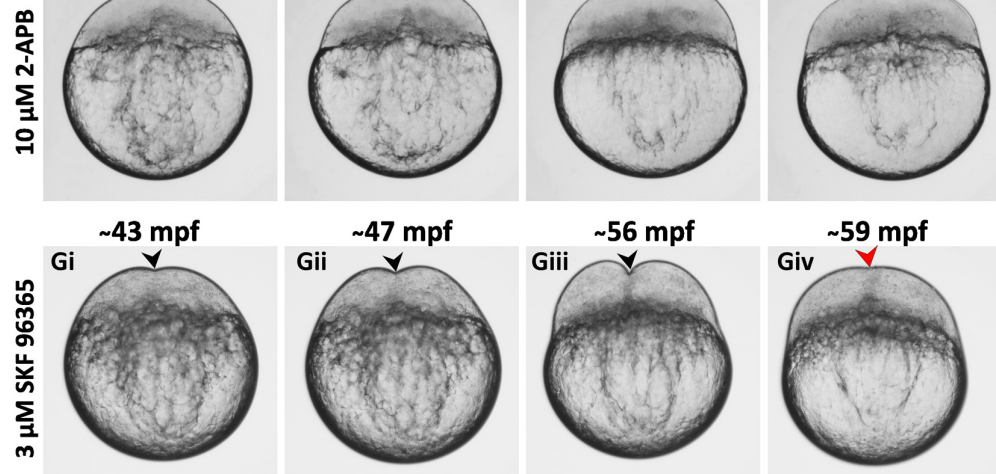

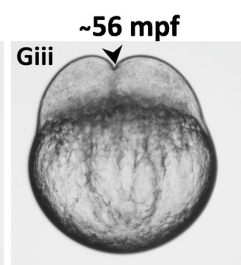

Fig. 1. Effect of SOCE and other $\mathrm{Ca}^{2+}$ channel inhibitors on furrow positioning, propagation, deepening and apposition of the first cell division cycle in zebrafish embryos. These are bright-field images of embryos that were (A) untreated or (B-G) that were treated with (B) $1 \%$ DMSO (control); (C) $3 \mu M M L 218$; (D) $100 \mu \mathrm{M}$ trans-Ned-19; (E) $20 \mu \mathrm{M} \mathrm{BTP-2;} \mathrm{(F)} 10 \mu \mathrm{M}$ 2-APB or (G) $3 \mu \mathrm{M}$ SKF 96365. Embryos are shown in a facial orientation. The indentations of the furrow during positioning (A-G, panel shown by black arrowheads, while completely apposed furrows furrows following treatment with 2-APB or SKF 96365 (F-G, panel iv) are shown by red arrowheads. Scale bar is $200 \mu \mathrm{m}$. i), propagation ( $A-G$, panel ii) and deepening ( $A-G$, panel iii) are ( $A-E$, panel iv) are shown by blue arrowheads and the regressed 
pore-forming subunit of the store-operated channel (SOC), or via TRPC, another $\mathrm{Ca}^{2+}$ channel in the PM (Parekh and Putney, 2005). It has been proposed that SOCE shuts down during cell division (Smyth and Putney, 2012). However, data supporting this suggestion have been mainly derived from small, flat tissue culture cells (Preston et al., 1991; Tani et al., 2007), where size and geometry, as well as post-cytokinesis cell separation, may not require the same sort of sustained $\mathrm{Ca}^{2+}$ signaling that large egg cells require during cytokinesis.

Here, for the first time, we report that in the large, meroblastically cleaving eggs of zebrafish, SOCE does not appear to be required for mitosis, furrow positioning, or furrow propagation (where $\mathrm{Ca}^{2+}$ stored in the ER seems to be adequate), but it does appear to be essential for sustaining elevated levels of $\left[\mathrm{Ca}^{2+}\right]_{\mathrm{i}}$ for the extended periods that are required during furrow deepening and daughter cell apposition.
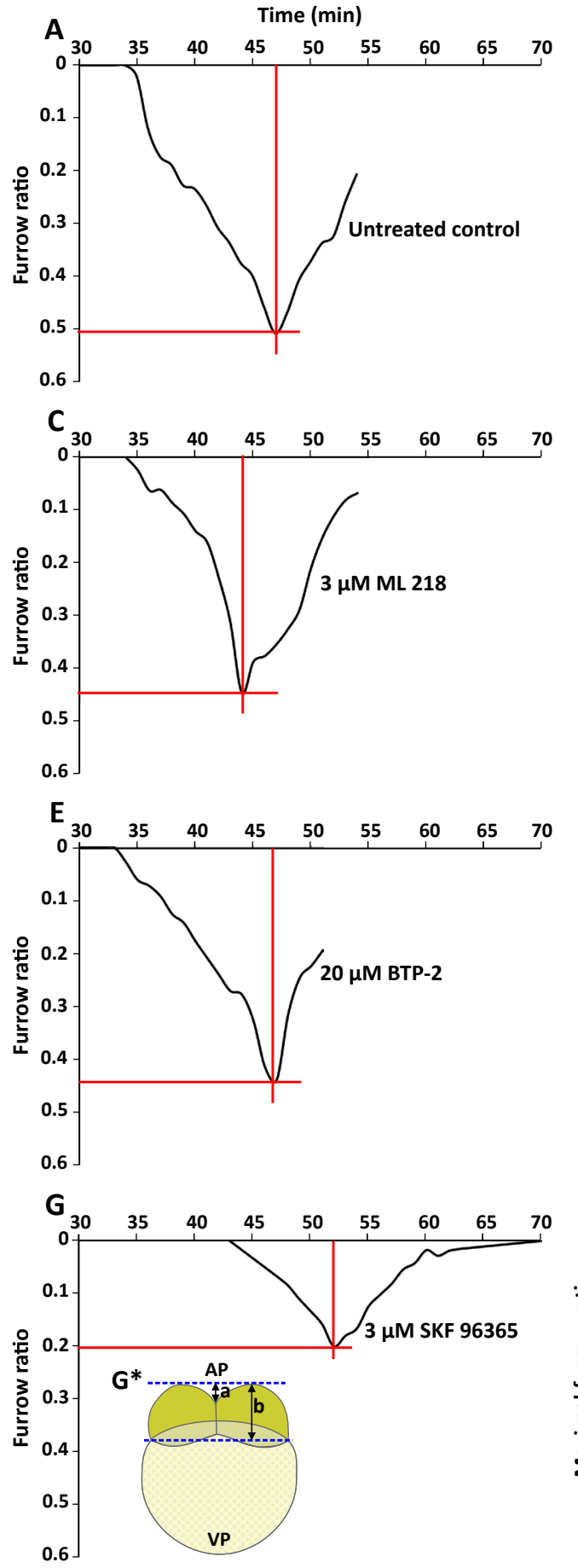
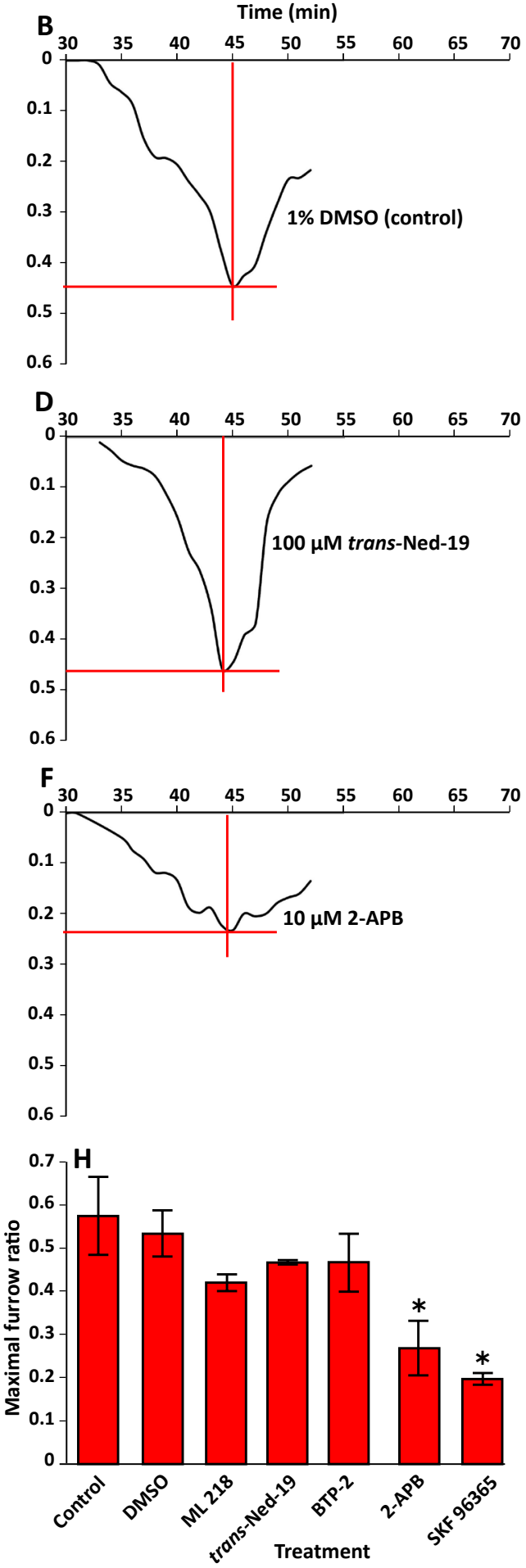

Fig. 2. Effect of SOCE and other $\mathrm{Ca}^{2+}$ channel inhibitors on the normalized furrow ratio during the first cell division cycle. (A-G) Line graphs of representative embryos that were (A) untreated or(B-G) that were treated with (B) $1 \%$ DMSO (control); (C) $3 \mu \mathrm{M} \mathrm{ML}$ 218; (D) 100 $\mu$ Mtrans-Ned-19; (E) $20 \mu \mathrm{M}$ BTP-2; (F) $10 \mu \mathrm{M} 2-A P B$ or (G) $3 \mu \mathrm{MSKF}$ 96365. (G*) The normalized furrow ratio was obtained by measuring the depth of the furrow (a) and the height of the blastodisc (b) and then calculating (a)/ (b). (H) Bar chart to show the maximum furrow ratio (i.e., during deepening) in embryos that were untreated or else treated as described above for panels A-G. The n-numbers are as follows: untreated $(n=4)$, and treated with DMSO $(n=4), M L 218(n=3)$, trans-Ned-19 $(n=3)$, BTP-2 (n=5), 2-APB $(n=6)$, and SKF $96365(n=3)$. The asterisks indicate data that are significantly different from the untreated controls at $p<0.01$. 


\section{Results}

Effect of SOCE inhibitors on furrow positioning, propagation and deepening during the first cell division cycle

Embryos were treated with three SOCE inhibitors, BTP-2, 2-APB and SKF 96365, starting at 15 min post-fertilization (mpf; allowing time to dechorionate the newly fertilized embryos) and throughout the first cell division cycle. Some embryos were simply bathed in Danieau's solution alone (untreated) or were incubated with Danieau's solution containing DMSO, as controls, or with ML 218, a known T-type $\mathrm{Ca}^{2+}$ channel blocker, or trans-Ned-19, a two-pore channel inhibitor. With the embryos in a facial orientation, a series of bright-field images was then acquired during furrow positioning, propagation, deepening and apposition (Fig. 1).

In the untreated and 1\% DMSO-treated control embryos (Fig. $1 \mathrm{~A}, \mathrm{~B})$, an indentation at the apex of the blastodisc at $~ 35 \mathrm{mpf}$ indicated the appearance of the cleavage furrow arc (i.e., furrow positioning; see black arrowheads in Fig. $1 \mathrm{Ai}, \mathrm{Bi}$ ). Within approximately 4-5 min, (i.e., $39 \mathrm{mpf}$ ) the furrow had propagated to the edges of the blastodisc (see black arrowheads in Fig. 1 Aii,Bii). By $\sim 47 \mathrm{mpf}$, the furrow had deepened to separate the two daughter cells (see black arrowheads in Fig. 1 Aiii,Biii) and by 54-55 mpf, furrow apposition was complete (see the blue arrowheads indicating the clearly apposed furrow in Fig. 1 Aiv,Biv).

Embryos treated with the T-type $\mathrm{Ca}^{2+}$ channel blocker, ML 218 at $3 \mu \mathrm{M}$ (Fig. $1 \mathrm{C})$ or the two-pore channel blocker, trans-Ned-19 at $100 \mu \mathrm{M}$ (Fig. 1D), also exhibited a normal cytokinesis of the first cell division cycle such that furrow positioning (Fig. $1 \mathrm{Ci}, \mathrm{Di}$ ), propagation (Fig. 1 Cii,Dii), deepening (Fig. 1 Ciii,Diii), and apposition (Fig. 1 Civ,Div) occurred normally and with similar timing, when compared with the untreated and DMSO-treated control embryos.

On the other hand, the SOCE inhibitors BTP-2, 2-APB and SKF 96365 had a variable effect on cytokinesis. For example, embryos treated with $20 \mu \mathrm{M}$ BTP-2 (Fig. 1E) exhibited normal furrow positioning (Fig. 1Ei), propagation (Fig. 1Eii), deepening (Fig. 1Eiii) and apposition (Fig. 1Eiv), with regards to both timing and furrow formation, when compared with the untreated and DMSO-treated control embryos. However, when embryos were treated with 10 $\mu \mathrm{M} 2-\mathrm{APB}$, furrow positioning and propagation occurred (see black arrowheads in Fig. 1Fi, $1 \mathrm{Fii}$ ) but the furrow did not deepen normally (see black arrowhead in Fig. 1Fiii), and thus two daughter cells were not formed. As furrow deepening was abnormal, there was no apposition and indeed the furrow regressed (see red arrowhead in Fig. 1Fiv). In addition, when embryos were treated with $3 \mu \mathrm{M}$ SKF 96365, furrow positioning and propagation occurred (see black arrowheads in Fig. 1Gi, $1 \mathrm{Gii}$ ) and furrow deepening appeared at least to be initiated (see black arrowhead in Fig. 1Giii), but the furrow did not deepen all the way to the top of the yolk to separate the two daughter cells and, similar to the 2-APB treated embryos, furrow regression occurred (see red arrowhead in Fig. 1 Giv). Furthermore, there was a distinct delay in the initiation of cytokinesis in embryos treated with SKF 96365 with furrow positioning occurring at $\sim 43 \mathrm{mpf}$, when compared with a positioning time of $\sim 35 \mathrm{mpf}$ for the controls and various other drug treatments. Once cytokinesis was initiated in the SKF 96365-treated embryos, however, it progressed at approximately the same rate as that in the control embryos such that furrow propagation occurred within $\sim 4$ min of positioning and furrow deepening (albeit abnormal) took place within $\sim 8-9$ min of propagation (compare the timing of Fig. $1 \mathrm{G}$ with that of Fig. $1 \mathrm{~A}-\mathrm{F})$.

\section{Effect of SOCE inhibitors on the changes in furrow depth during cytokinesis}

Using the bright-field images acquired for the representative untreated embryos and for those treated with the various pharmacological agents (of which just a few are shown in Fig. 1), the depth of the furrow was measured throughout the first cell division cycle (Fig. 2). The data was normalized by dividing the furrow depth by the overall height of the blastodisc (as shown in Fig. 2G*) to allow for differences in the size of the embryos. Untreated control embryos (Fig. 2A) initiated cytokinesis with furrow positioning at $\sim 35 \mathrm{mpf}$ and reached maximal furrow deepening at $\sim 47 \mathrm{mpf}$ with a

\section{Untreated control}

mitosis. Representative (A-H panel i) bright-field and (A-H, panel ii) fluorescence images of embryos injected with SYTOX Green to label the nuclei and then either (A-D) untreated or (E-H) incubated with SKF 96365 from the 1-cell to 64-cell stages. Images are shown when the untreated controls reached the (A) 2-cell, (B) 4-cell, (C) 8-cell and (D) 64-cell stages and (E-H) at equivalent stages for the SKF 96365-treated embryos. Blue arrowheads in Ai-Di indicate the plasma membrane that forms between cells following successful cytokinesis and red arrowheads in Aii-Hii indicate the cell nuclei. Scale bar is $200 \mu \mathrm{m}$.
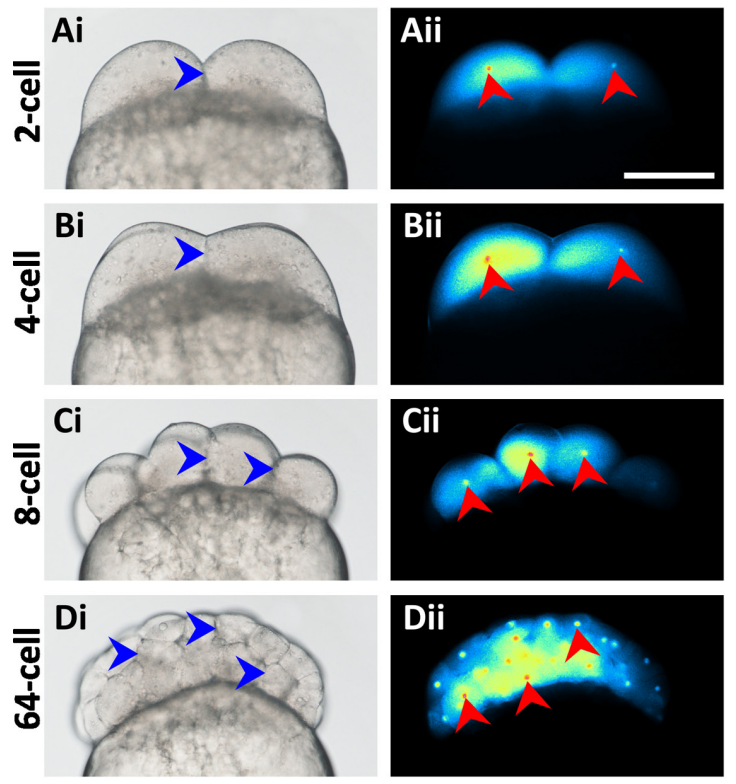

$3 \mu \mathrm{M}$ SKF 96365
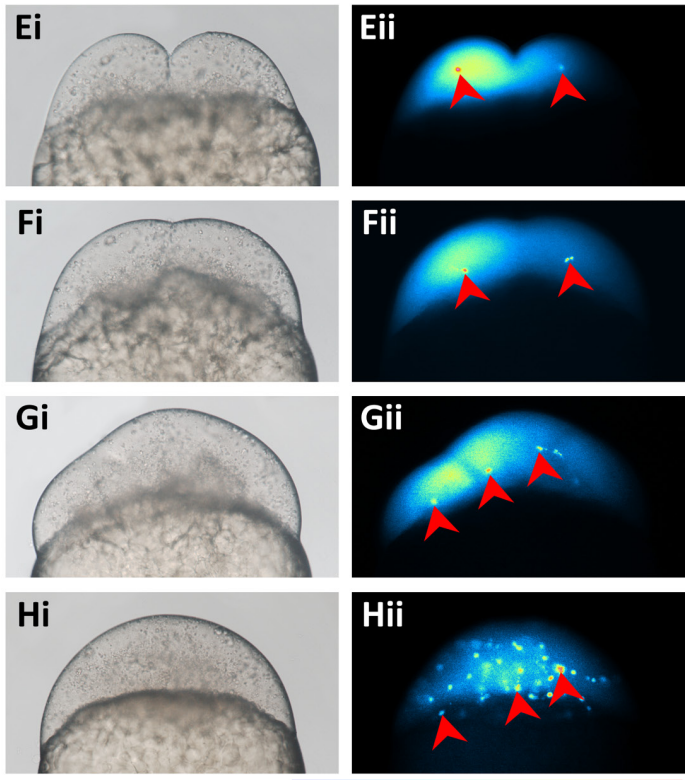

Hii

Relative fluorescence Intensity Low 
A $1 \%$ DMSO

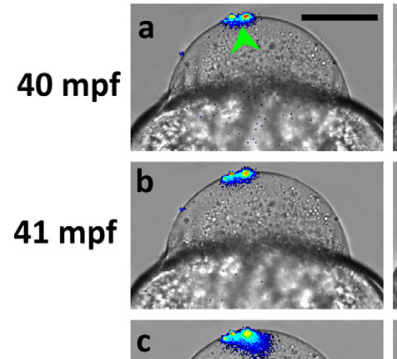

$42 \mathrm{mpf}$

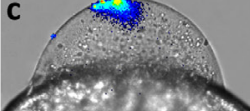

$43 \mathrm{mpf}$
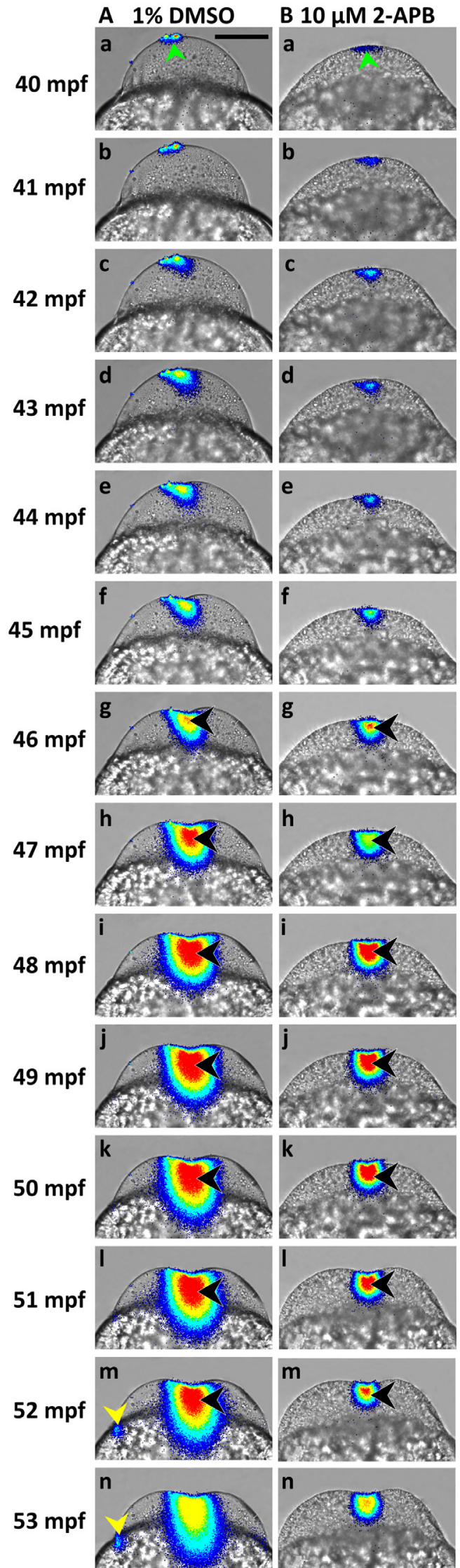

n

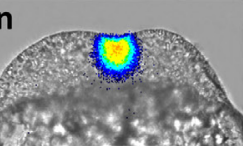

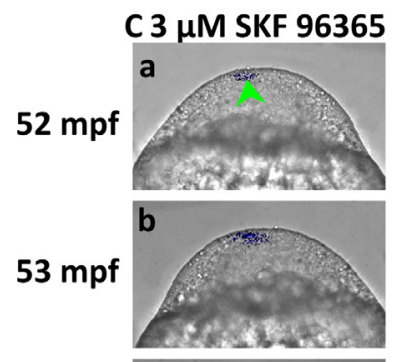
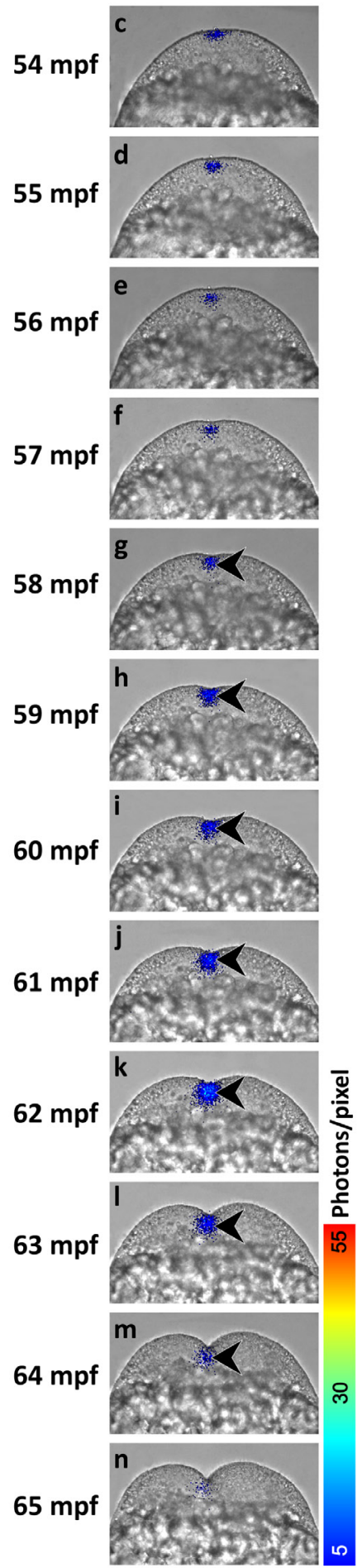

furrow ratio of $\sim 0.5$. Similarly, embryos treated with DMSO (Fig. 2B), ML 218 (Fig. 2C), trans-Ned-19 (Fig. 2D), BTP-2 (Fig. 2E) and 2-APB (Fig. 2F) also initiated cytokinesis between $30-35 \mathrm{mpf}$ and reached maximal furrow deepening between 44-47 mpf. On the other hand, SKF 96365-treated embryos (Fig. $2 \mathrm{G}$ ) only initiated cytokinesis at $\sim 43 \mathrm{mpf}$, i.e., some 8-10 min after the untreated embryos and those treated with other channel inhibitors. Furthermore, embryos treated with DMSO, ML218, trans-Ned-19 or BTP-2 (Fig. 2B-2E) were calculated to have a maximal furrow ratio of between 0.4-0.5, whereas those treated with 2-APB or SKF 96365 (Fig. 2F, $2 G$ ) had a maximal furrow ratio value of just 0.2 to 0.25 . The effect of these various treatments on the maximal furrow ratio is also shown in the bar chart (Fig. 2H) when the data from several experiments are shown. The maximal furrow ratio of embryos treated with 2-APB or SKF 96365 was significantly lower than that of the other treatments at $p<0.01$.

\section{Effect of SKF 96365 on mitosis during the cell cycle}

As SKF 96365 was shown to inhibit cytokinesis, its effect on mitosis was investigated during the first 6 cell division cycles (Fig. 3). Embryos were injected with SYTOX Green to label the nuclei and then either left untreated (Fig. 3 A-D) or incubated with SKF 96365 (Fig. 3 E-H). Bright-field (Fig. 3 Ai$\mathrm{Hi}$ ) and fluorescence (Fig. 3 Aii-Hii) images were then acquired from the 2-cell to 64-cell stages. In untreated embryos undergoing normal cytokinesis, the daughter cells were separated by clear plasma membranes (see blue arrowheads in Fig. 3 Ai-Di), there was one (or sometimes two) nuclei per cell (depending on the stage of the cell cycle; red arrowheads in Fig. 3 Aii-Dii), and these were thus evenly arranged throughout the blastoderm. In SKF 96365-treated embryos, where cytokinesis was inhibited (as shown by the lack of plasma membranes and thus an absence of distinct cells; Fig. $3 \mathrm{Ei}-\mathrm{Hi}$ ), mitosis still occurred although the nuclei had no plasma membrane boundaries and so they were arranged in a less regular manner throughout the blastoderm (Fig. 3 Eii-Hii).

Fig. 4. The effect of 2-APB and SKF 96365 on the cytokinetic $\mathrm{Ca}^{2+}$ transients generated during the first cell division cycle. Representative sequences of images from three aequorin loaded embryos (all in a facial orientation) illustrating the changes in intracellular free $\mathrm{Ca}^{2+}$ when incubated with (A) $1 \% D M S O$, (B) $10 \mu \mathrm{M} 2-A P B$ or (C) 3 $\mu M$ SKF 96365. The luminescent images (in pseudocolor) are superimposed on the corresponding bright-field images and represent 1 min of accumulated light, and consecutive panels are stepped at 1-min intervals starting at the time of development (in min post-fertilization; mpf) shown. Yellow arrowheads in panels 'Am' and 'An' indicate a wound signal from the site of aequorin injection. The color scale indicates luminescent flux in photons/pixel. Scale bar is $200 \mu \mathrm{m}$. 


\section{Effect of 2-APB and SKF 96365 on the cytokinetic $\mathrm{Ca}^{2+}$ transients}

Figure 4 shows the sequence of $\mathrm{Ca}^{2+}$ transients that accompany the first cell division cycle seen from a facial view in representative embryos treated with DMSO (Fig. 4A), $10 \mu \mathrm{M}$ 2-APB (Fig. 4B) or $3 \mu \mathrm{M}$ SKF 96365 (Fig. 4C). The $\mathrm{Ca}^{2+}$ transients generated in the DMSO-treated embryo appeared to be somewhat similar (with respect to both timing and pattern) to those generated in untreated control embryos (compare Fig. 4A, panels a-n, with Fig. 2A of Webb et al., 1997). For example, in both cases the $\mathrm{Ca}^{2+}$ transients of the first cell division cycle lasted for around 12-13 min and they consisted of clearly defined furrow positioning, propagation, deepening and apposition $\mathrm{Ca}^{2+}$ signals. In the representative DMSO-treated embryo $(n=6)$, the first localized subsurface elevation in intracellular free $\mathrm{Ca}^{2+}$ (furrow positioning signal) occurred at $\sim 40 \mathrm{mpf}$ (see
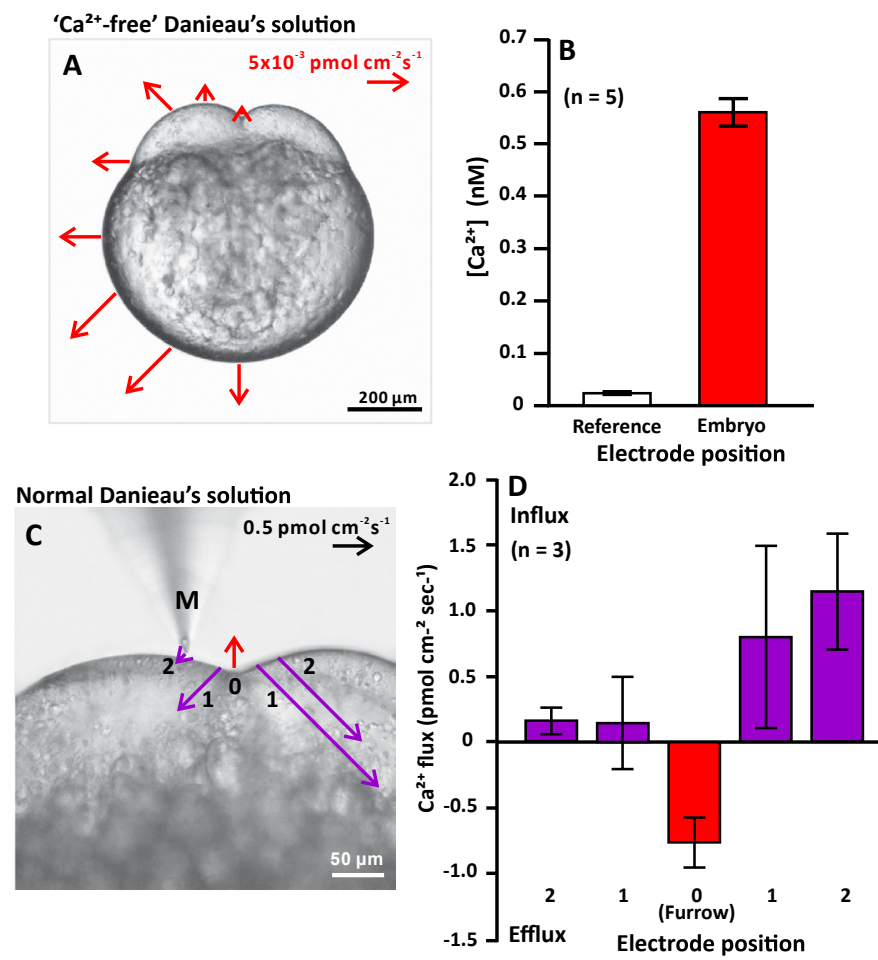

Fig. 5. Scanning ion-selective electrode measurements to determine the level of extracellular $\mathrm{Ca}^{2+}$ around embryos. (A,B) Effect of incubation in $\mathrm{Ca}^{2+}$-free Danieau's solution on the $\mathrm{Ca}^{2+}$ fluxes in the immediate vicinity of dividing zebrafish embryos. (A) Bright-field image of a representative embryo during furrow deepening of the first cell division cycle, onto which is superimposed a vector diagram showing a distinct efflux of $\mathrm{Ca}^{2+}$ from around the embryo (both yolk and dividing blastodisc). (B) The bar chart shows the mean \pm SEM $\left[\mathrm{Ca}^{2+}\right]$ generated in the near vicinity (i.e., within just $5 \mu \mathrm{m}$ ) of 5 embryos, when compared with that measured at a reference position $>1 \mathrm{~mm}$ away from the embryos. (C,D) The Ca $\mathrm{Ca}^{2+}$ fluxes measured in the region of the cleavage furrow during the first cell division cycle in embryos bathed in normal (i.e., Ca ${ }^{2+}$-containing) Danieau's solution. (C) Bright-field image of a representative embryo, onto which is superimposed a vector diagram showing an efflux of $\mathrm{Ca}^{2+}$ in the base of the furrow (position 0) and an influx of $\mathrm{Ca}^{2+}$ along the sides of the furrow (positions 1 and 2). ' $M$ ' is the microelectrode. (D) The bar chart illustrates this same pattern of efflux and influx in 3 embryos and the numbers 0,1 and 2 indicate the relative positions that the measurements were made (as indicated in panel C). Scale bars are $200 \mu \mathrm{m}$ (A) and $50 \mu \mathrm{m}$ (B). green arrowhead in Fig. 4Aa). This then developed into the furrow propagation signal, which lasted between $\sim 41-45 \mathrm{mpf}$ (Fig. 4Ab4Af). As the propagation wave fronts approached the margins of the blastodisc, another distinct $\mathrm{Ca}^{2+}$ signal, the furrow deepening signal, arose in the central region of the blastodisc and this accompanied the deepening process that resulted in the single large cell being divided into two. The deepening $\mathrm{Ca}^{2+}$ signal lasted for $\sim 6 \mathrm{~min}$, (i.e., from $\sim 46 \mathrm{mpf}$ to $52 \mathrm{mpf}$; see black arrowheads in Fig. 4Ag-4Am). At the end of cytokinesis (i.e., by $\sim 53 \mathrm{mpf}$; Fig. 4An), the onset of furrow apposition was accompanied by a reduction in the central region of the deepening $\mathrm{Ca}^{2+}$ transient.

In the representative 2-APB-treated embryo $(n=6)$, a localised subsurface elevation of intracellular $\mathrm{Ca}^{2+}$ similar to that observed in the DMSO-treated control embryo was generated at $\sim 40 \mathrm{mpf}$ (see green arrowheads in Fig. 4Ba and Fig. 4Aa). Again, similar to the DMSO control, this positioning $\mathrm{Ca}^{2+}$ signal then developed into the furrow propagation signal, which lasted between $\sim 41-45 \mathrm{mpf}$ (Fig. $4 \mathrm{Bb}-\mathrm{Bf})$. As the propagation wave fronts approached the margins of the blastodisc, a furrow deepening $\mathrm{Ca}^{2+}$ signal arose in the central region of the blastodisc and again lasted for $\sim 6 \mathrm{~min}$ (i.e., from 46 mpf to 52 mpf; see black arrowheads in Fig. 4B g-m), after which there was a reduction in the $\mathrm{Ca}^{2+}$ transient in the central region (Fig. $4 \mathrm{Bn})$. Thus, the 2-APB-treated embryo exhibited a similar pattern of cytokinetic $\mathrm{Ca}^{2+}$ transients as the DMSO control. However, the volume of the deepening $\mathrm{Ca}^{2+}$ transient generated in the 2-APB-treated embryos was considerably lower than that of the DMSO-treated controls, both laterally across the width of the blastodisc, and from the apex of the blastodisc toward the yolk.

In the representative SKF 96365-treated embryo (Fig. 4C), a positioning $\mathrm{Ca}^{2+}$ signal was clearly observed at $52 \mathrm{mpf}$, i.e., some 12 min after the same signal was generated in the DMSO-control and 2-APB-treated embryos (see green arrowhead in Fig. 4Ca and compare Fig. $4 \mathrm{Ca}$ with Fig. $4 \mathrm{Aa}, \mathrm{Ba}$ ). This $\mathrm{Ca}^{2+}$ positioning signal developed into a small propagation signal, which lasted between $\sim 53-57 \mathrm{mpf}$ (Fig. 4C c-f), after which a very small (both from the volume and $\left[\mathrm{Ca}^{2+}\right]$ viewpoint) deepening $\mathrm{Ca}^{2+}$ signal was generated between 58-64 mpf (see black arrowheads in Fig. $4 \mathrm{C} \mathrm{g-m}$ ). This deepening $\mathrm{Ca}^{2+}$ transient had almost completely disappeared by 65 mpf (Fig. 4Cn) such that there was no distinct $\mathrm{Ca}^{2+}$ apposition transient. Thus, in the presence of SKF 96365, the initiation of the cytokinetic $\mathrm{Ca}^{2+}$ signals was delayed, and when signals did occur, they were very small when compared with the DMSO-treated control embryos undergoing normal cytokinesis. However, once the $\mathrm{Ca}^{2+}$ positioning signal was in place, then the timing of the subsequent propagation, deepening and apposition $\mathrm{Ca}^{2+}$ signals was very similar to the controls.

\section{$\mathrm{Ca}^{2+}$ flux measurements}

The $\mathrm{Ca}^{2+}$ fluxes in the medium around dechorionated embryos bathed in so-called ' $\mathrm{Ca}^{2+}$-free' Danieau's solution (Webb et al., 1997 ; i.e., prepared without $\mathrm{Ca}\left(\mathrm{NO}_{3}\right)_{2}$ but with $0.3 \mathrm{mM} \mathrm{EGTA}$ ) were measured using a scanning ion-selective microelectrode specific for $\mathrm{Ca}^{2+}$ (see Materials and Methods). Figure 5A shows the fluxes measured around a representative embryo $(n=3)$ during deepening of the first cell division cycle; in all regions of the blastoderm and yolk a distinct efflux of $\mathrm{Ca}^{2+}$ was recorded. Data from 3 embryos are presented in Fig. 5B; they show that when the microelectrode was located $>1 \mathrm{~mm}$ away from the embryo (i.e. in the 'Reference' position), the $\left[\mathrm{Ca}^{2+}\right]$ was $\sim 0.03 \pm 0.002 \mathrm{nM}$, whereas when it was 

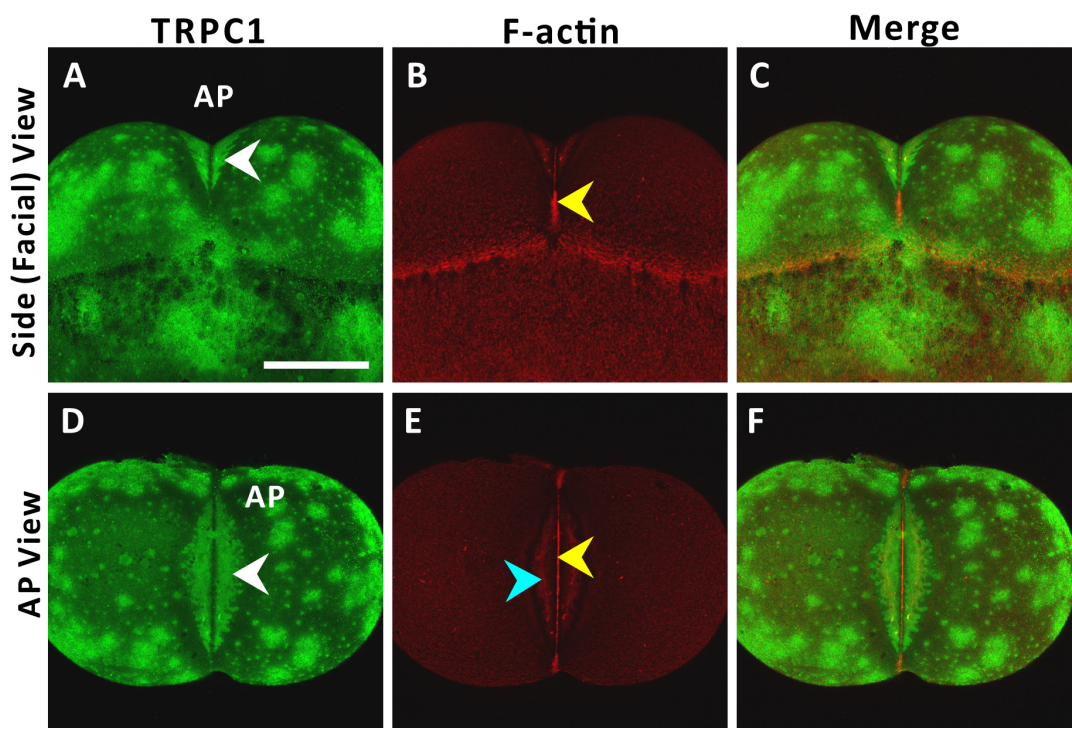

Fig. 6. Localization of TRPC1 in the sides of the cleavage furrow during deepening of the first cell division cycle. Representative $(n=3)$ series of single confocal images that have been projected as single images to show the localization of (A,D) TRPC1, (B,E) F-actin and (C,F) both TRPC1 and F-actin from a (A-C) side facial view and (D-F) animal pole (AP) view. The white arrowheads indicate TRPC1 in the deepening furrow; while the yellow arrowheads show the F-actin-rich contractile band and the blue arrowhead shows the peri-cleavage F-actin enrichments located on either the side of the deepening furrow. Scale bar is $200 \mu \mathrm{m}$.

positioned just 5 um away from the embryo (i.e., 'Embryo' on the graph), the mean $\left[\mathrm{Ca}^{2+}\right]$ was significantly higher, at $\sim 0.56 \pm 0.03 \mathrm{nM}$.

The $\mathrm{Ca}^{2+}$ fluxes around dechorionated embryos bathed in normal (i.e., $\mathrm{Ca}^{2+}$-containing) Danieau's solution were also measured in the region of the cleavage furrow as well as on either side of the furrow during deepening of the first cell division cycle. Figure $5 \mathrm{C}$ shows a representative embryo $(n=5)$ where a small efflux of $\mathrm{Ca}^{2+}$ occurred at the base of the furrow directly above the contractile apparatus. However, a distinct influx of $\mathrm{Ca}^{2+}$ was measured on either side of the deepening cleavage furrow. This same efflux to influx pattern is also shown when data from 3 embryos are presented as a bar chart (Fig. 5D).

\section{Localisation of TRPC1 in the sides of the deepening cleavage furrow during cytokinesis}

Embryos were fixed during furrow deepening of the first cell division cycle and then immunolabeled with an antibody for TRPC1 and co-stained with fluorescent-phalloidin to label F-actin (Fig. 6). TRPC1 is a component of SOCE and it is reported to be inhibited by both 2-APB and SKF 96365 (Bomben and Sontheimer, 2008) but not by L-type voltage-gated $\mathrm{Ca}^{2+}$ channel blockers such as nifedipine ( $\mathrm{Ng}$ et al., 2012). Confocal images were then acquired with embryos in a side (facial) view (Fig. 6A-C) and animal pole view (Fig. 6D-F). Both of these views show that TRPC1 was localised to the sides of the deepening cleavage furrow (see white arrowheads in Fig. 6A, C, D, F) in the same general location as the peri-cleavage $\mathrm{F}$-actin enrichments (see blue arrowhead in Fig. 6E). TRPC1 was not, however, co-localised with the plasma membrane directly adjacent to the contractile band at the base of the cleavage furrow (see yellow arrowheads in Fig. 6B, C, E, F).

\section{Discussion}

Furrow deepening and membrane remodelling are two of the key events during division of the large cells that constitute early zebrafish embryos. In their absence, daughter cells do not separate correctly, and even when mitosis occurs normally, a non-viable multinucleate single cell blastoderm forms. Several functions have been attributed to the $\mathrm{Ca}^{2+}$ signal that accompanies furrow deepening. The first is that it acts to stimulate contraction of the actomyosin band (assembled during the previous positioning and propagation stages), resulting in furrow ingression and the separation of daughter cells. The calcium/calmodulin-dependent enzyme, myosin light chain kinase (MLCK) has been proposed as a possible $\mathrm{Ca}^{2+}$-sensitive molecular target for the deepening transient, where $\mathrm{Ca}^{2+}$-activated $\mathrm{MLCK}$ phosphorylates the Ser-19 site of MLC and thus triggers contraction of the actomyosin band (Chang and Meng, 1995). In support of this proposition, GFP-tagged calmodulin has been reported to be reorganized into the presumptive cleavage furrows of both HeLa cells (Li et al., 1999) and zebrafish embryos (Webb et al., 2013) prior to the appearance of the furrow at the cell surface. The membrane remodelling that occurs during furrow deepening consists of two sequential events: vesicle recruitment to the deepening furrow followed by vesicle fusion with the ingressing furrow membrane ( $\mathrm{Li}$ et al., 2006). Indeed, the cognate v- and t-SNARES, VAMP-2 and SNAP-25, respectively, have been shown to play an essential role in the latter of these two events. Furthermore, transport of VAMP2 vesicles to the furrow along the furrow microtubule (MT) array is mediated by a kinesin-like protein, Kif23, and vesicle transport and subsequent fusion are both $\mathrm{Ca}^{2+}$-dependent processes ( $\mathrm{Li}$ et al., 2008). During furrow apposition, Kif23, VAMP-2 and SNAP-25 continue to play an essential role in promoting daughter cell-to-cell adhesion, with a possible change in the VAMP-2 vesicle cargo from the new membrane components transported during deepening, to those required for cell adhesion (Li et al., 2006, 2008). It has been reported that there is a dynamic rearrangement of the ER into linear tracks within the cortex along the line of each cleavage plane prior to the positioning of the cleavage furrow at the surface (Lee et al., 2004). Furthermore, when the leading edge of the furrow ingresses during the deepening phase, the rearranged cortical ER accompanies it, and continues to act as a highly localized intracellular $\mathrm{Ca}^{2+}$ store (Webb and Miller, 2007; Li et al., 2008).

It has long been reported that MTs and the ER are highly interdependent structures (Terasaki et al., 1986; Waterman-Storer and Salmon, 1998; Grigoriev et al., 2008). Indeed, during the early embryonic cleavages of zebrafish development, the rearrangement of the cortical ER is thought to be brought about via the action of MTs in the form of a pre-furrowing mid-spindle MT array (pf-MTA; Lee et al., 2004). As the furrow ingresses, the pf-MTA develops into a furrow ingression MTA (i.e., fi-MTA), which in turn develops into a furrow apposition MTA (or fa-MTA). Such structures have been described previously in both zebrafish (Jethusasan, 1998; Lee et al., 2004) and Xenopus (Danilchik et al., 1998; Takayama et al., 2002). Furthermore, MTs have also been directly implicated in the 
Fig. 7. Schematic illustration to show the possible role of store-operated $\mathrm{Ca}^{2+}$ entry, in combination with other sources of $\mathrm{Ca}^{2+}$ release during cleavage furrow deepening in zebrafish embryos. Hypothetical model of a facial view of a blastodisc to illustrate how $\mathrm{Ca}^{2+}$ released via activation of $I P_{3} R s$ in the $E R$ might be sufficient to generate the early deepening $\mathrm{Ca}^{2+}$ transient but how $\mathrm{Ca}^{2+}$ entering from the outside of the embryo via SOCE might be required to maintain the high level of $\mathrm{Ca}^{2+}$ in the furrow region required for subsequent deepening. The precise role (if any) of Orai1, STIM1 and TRPCs in store-operated $\mathrm{Ca}^{2+}$ entry during furrow deepening in zebrafish embryos is still unclear. Modified from Fig. 5 of Webb and Miller (2007).

release of $\mathrm{Ca}^{2+}$ from the ER (Tasaka et al., 1991). Thus, a second possible task of the fiMTA (along with providing tracks for vesicle transport) might be to help position the ER close to the ingressing furrow membrane, and in this way perhaps support SOCE during the furrow deepening and apposition processes. It has been reported that within the ER membrane, STIM1 - the ER $\mathrm{Ca}^{2+}$ sensor, and thus a protein that is essential for SOCE - does not distribute randomly, but appears to align partially with the MTs (Smyth et al., 2007; Fig. 7). It has been proposed that the MT-plus-end-tracking protein EB1 binds directly with STIM1 and forms EB1-dependent "comet-like" accumulations at the sites where polymerizing MT ends come in contact with the ER network (Grigoriev et al., 2008).

It has also been proposed that the ER alone is the primary $\mathrm{Ca}^{2+}$ store for generating at least the first two of the cytoplasmic $\mathrm{Ca}^{2+}$ transients in zebrafish embryos via release mainly through $\mathrm{IP}_{3} \mathrm{Rs}$ (Créton et al., 1998; Chang and Meng, 1995; Webb et al., 1997; Lee et al., 2003, 2006). Our new evidence supports this proposition and suggests that the ER (and perhaps other intracellular $\mathrm{Ca}^{2+}$ stores), has sufficient $\mathrm{Ca}^{2+}$ to generate these signals without the need to stimulate SOCE (Fig. 1Gi and 1Gii; Fig 2G; Figure 4C). However, sustaining longer-duration $\mathrm{Ca}^{2+}$ signals, such as those generated during the deepening and apposition stages of cytokinesis in these large embryonic cells appears to require the entry of extracellular $\mathrm{Ca}^{2+}$, which is triggered following depletion of the ER $\mathrm{Ca}^{2+}$ stores. It has been suggested that SOCE is dependent on the ER $\mathrm{Ca}^{2+}$ sensor, STIM1, which moves within the ER membrane to become distributed into puncta in close apposition to the PM (Smyth et al., 2007). In a manner not yet fully understood, STIM1 then activates either an Orai or a TRPC channel in the PM, thus allowing extracellular $\mathrm{Ca}^{2+}$ to enter the cell across the PM (Liou et al., 2005; Hawavitharana et al., 2007; DeHaven et al., 2008), which in our case is that of the ingressing
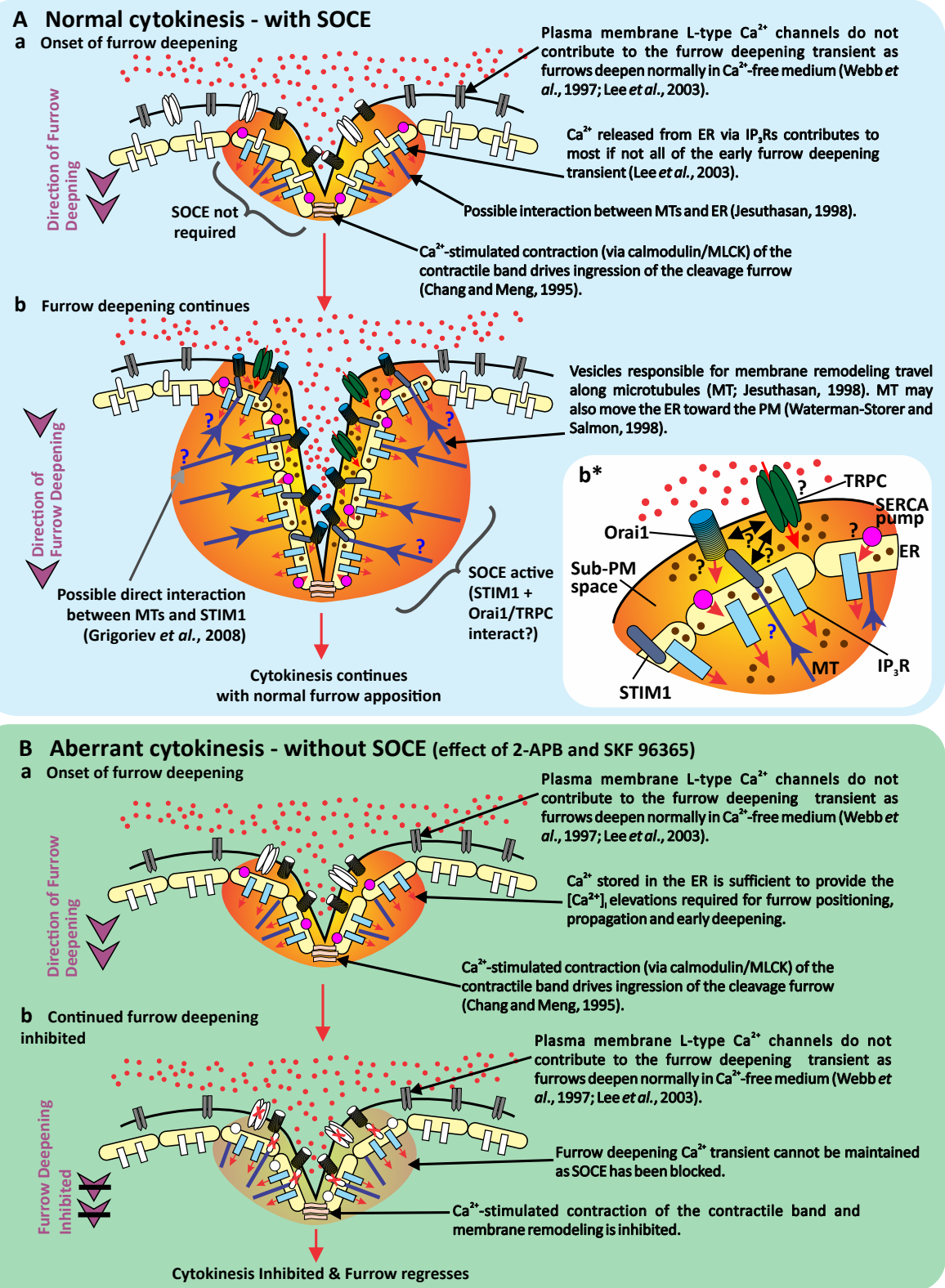

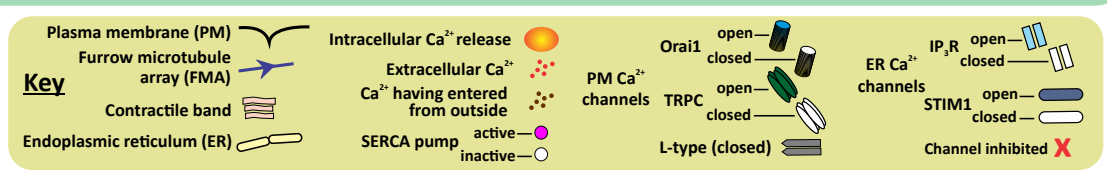

furrow. However, by directly challenging the deepening furrow via the injection of heparin, which is a competitive antagonist of $I P_{3} R$, but does not directly affect SOCE (Parekh and Putney, 2005), Lee et al., (2003) were able to block the deepening $\mathrm{Ca}^{2+}$ transient and thus inhibit furrow ingression. This suggests that the $\mathrm{Ca}^{2+}$ entering the cell via SOCE is not directly utilized to generate the deepening transient, but that it is first loaded into the ER (through SERCA activity; Guerrero-Hernández et al., 2014) for subsequent release via IP $R$. This might explain the ability of injected heparin to block the deepening $\mathrm{Ca}^{2+}$ transients and thus inhibit the completion of cytokinesis even if SOCE is active. This also suggests a mechanism of rapidly refilling the ER from the restricted sub-plasmalemmal 
space between the PM and the ER (Chan et al., 2003).

Although a number of inhibitors are reported to block SOCE, none of them are completely specific and so it requires a degree of caution when interpreting data derived from their use (Derler et al., 2013; Table 1). In these experiments, we tested the effect of three reported SOCE inhibitors, BTP-2, 2-APB and SKF 96365, on the first cell division cycle in zebrafish with the idea that their effects might provide information about the possible role of SOCE. Of the three inhibitors used, BTP-2 had no inhibitory effect on any of the stages of cytokinesis even when used at $20 \mu \mathrm{M}$, which is 4 -fold and 20 -fold higher than the concentrations reported to inhibit Orai1 in myotubes (Li et al., 2010) and in HEK293 cells and the DT40 chicken B-cell line (He et al., 2005), respectively. On the other hand, both 2-APB and SKF 96365 blocked furrow deepening such that the final stages of cytokinesis were incomplete and the furrows regressed (Fig. 1F, 1G). Of all the SOCE inhibitors used, 2-APB is known to be the least selective, being reported to inhibit a wide range of different channels and pumps (Maruyama et al., 1997; Missiaen et al., 2001; Bilmen et al., 2002; Hu et al., 2004; Bai et al., 2006; DeHaven et al., 2008; Togashi et al., 2008; Bomben and Sontheimer, 2008; Yang et al., 2011; Kovacs et al., 2012). Furthermore, its specific action on SOCE has been reported to be concentration dependent such that at low concentrations (i.e., 3-10 $\mu \mathrm{M}$ ), 2-APB activated STIM1 and Orai1 in HEK 293 cells, whereas at higher concentrations (i.e., 30-50 $\mu \mathrm{M})$ they were inhibited (DeHaven et al., 2008). We have previously shown in zebrafish, that when used at $25 \mu \mathrm{M}, 2-\mathrm{APB}$ blocked furrow deepening but did not affect furrow positioning ( $\mathrm{Li}$ et al., 2008). Here, when used at $10 \mu \mathrm{M}, 2$-APB had a similar effect on cytokinesis such that furrow positioning and propagation appeared to occur normally but the furrow did not deepen all the way to the top of the yolk and it subsequently regressed. Furthermore, the $\mathrm{Ca}^{2+}$ signals generated were smaller in size and exhibited a lower luminescence intensity (Fig. 4B) than did those generated by the DMSO-treated control embryos (Fig. 4A) or untreated embryos (Webb et al., 1997). A similar effect was observed with the morespecific SOCE inhibitor, SKF 96365, which was shown to have a profound effect on furrow deepening as well as on the cytokinetic $\mathrm{Ca}^{2+}$ signals even when used at $3 \mu \mathrm{M}$ (i.e., some 7-fold lower than that previously reported to inhibit STIM1; Liou et al., 2005).
On the other hand, SKF 96365 had no effect on mitosis (Fig. 3), and had only a delaying effect (by 10 min; Figs. 1G, 2G, 4C) on furrow positioning and early propagation, which suggests that its effect is mainly on the furrow deepening process of cytokinesis rather than on cell division as a whole. It did, however, reduce the intensity of the positioning and propagating $\mathrm{Ca}^{2+}$ signals (Fig. 4C a-e), which also might be linked to an inhibition of SOCE. As SKF 96365 is also reported to block T-type $\mathrm{Ca}^{2+}$ channels (Bomben and Sontheimer, 2008), we also tested the effect of a specific T-type $\mathrm{Ca}^{2+}$ channel inhibitor, ML 218 (Xiang et al., 2011), and showed that cytokinesis progressed normally. The possible role of the two pore channel (TPC) in regulating cytokinesis via $\mathrm{Ca}^{2+}$ release from lysosomes was also tested via the introduction of the specific TPC inhibitor, trans-Ned-19 (Naylor et al., 2009), and again we showed that cytokinesis was normal (Fig. 1D).

These new data, which suggest that extracellular $\mathrm{Ca}^{2+}$ entering cells via SOCE does play a role in the final (i.e., deepening and apposition) stages of cytokinesis, contradict a previous report from our group, which suggested that the localized $\mathrm{Ca}^{2+}$ transients associated with furrow positioning, propagation and deepening do not require the presence of extracellular $\mathrm{Ca}^{2+}$ (Webb et al., 1997). In this early report, we tried to ensure that all possible traces of $\mathrm{Ca}^{2+}$ in the medium were chelated with EGTA, and we dechorionated the embryos to ensure that there was no $\mathrm{Ca}^{2+}$ immediately outside the plasma membrane. Furthermore, we subsequently reported that cytokinesis was not adversely affected by the presence of the voltage-gated $\mathrm{Ca}^{2+}$ channel antagonists, nifedipine and verapamil, in the bathing medium (Lee et al., 2003). At the time, this was interpreted as supporting the proposition that extracellular $\mathrm{Ca}^{2+}$ was not essential for generating any of the cytokinetic $\mathrm{Ca}^{2+}$ transients (Lee et al., 2003). In this new report, however, we addressed these conflicting results by reproducing (as far as possible) the so-called $\mathrm{Ca}^{2+}$-free conditions that were reported previously (Webb et al., 1997). Using a scanning ion-sensitive microelectrode system (Kühtreiber and Jaffe, 1990), we measured the extracellular [Ca $\left.{ }^{2+}\right]$ in the immediate vicinity around embryos (i.e., within $\sim 5 \mu \mathrm{m}$ of the embryo surface around both the yolk cell and dividing blastodisc), as well as at a position $>1 \mathrm{~mm}$ away from the embryo (Fig. 5A, B). Our new data show that in what we had previously described as 'Ca ${ }^{2+}$-free' conditions, there was an efflux of $\mathrm{Ca}^{2+}$ from all over the

TABLE 1

\section{THE SOCE AND OTHER $\mathrm{Ca}^{2+}$ CHANNEL INHIBITORS USED AND THEIR VARIOUS TARGETS}

\begin{tabular}{|c|c|c|c|}
\hline $\begin{array}{l}\text { Inhibitor (and } \\
\text { concentration used) }\end{array}$ & SOCE component(s) targeted & Some of the other reported targets and/or effects & References \\
\hline $\begin{array}{l}\mathrm{ML} 218 \\
(3 \mu \mathrm{M})\end{array}$ & None & Inhibits T-type $\mathrm{Ca}^{2+}$ channels at $3 \mu \mathrm{M}$. & Xiang et al., 2011 \\
\hline $\begin{array}{l}\text { Trans-Ned-19 } \\
(100 \mu \mathrm{M})\end{array}$ & None & Inhibits two-pore channels (TPCs) at $10-100 \mu \mathrm{M}$ & Naylor et al., 2009; Davies et al., 2012 \\
\hline $\begin{array}{l}\text { BTP-2 } \\
(20 \mu \mathrm{M})\end{array}$ & $\begin{array}{l}{ }^{1} \text { Inhibits Orai1 at } 5 \mu \mathrm{M} \\
{ }^{2} \text { Inhibits TRPC3 \& TRPC5 at } 1 \mu \mathrm{M}\end{array}$ & $\begin{array}{l}\text { 3 Inhibits CRAC channels at } 100 \mathrm{nM} \text {. } \\
{ }^{4} \text { Stimulates the TRPM4 channel at low nM concentrations. }\end{array}$ & $\begin{array}{l}{ }^{1} \mathrm{Li} \text { et al., } 2010 \\
{ }^{2} \mathrm{He} \text { et al., } 2005 \\
{ }^{3} \text { Zitt et al., } 2004{ }^{4} \text { Takezawa et al., } 2006\end{array}$ \\
\hline $\begin{array}{l}\text { 2-APB } \\
(10 \mu \mathrm{M})\end{array}$ & $\begin{array}{l}{ }^{5} \text { Activates STIM1 \& Orai1 at } 3-10 \mu \mathrm{M} \\
\text { Inhibits STIM1 \& Orai } 1 \text { at } 30-50 \mu \mathrm{M} \\
{ }^{7} \text { Inhibits TRPC } 1,3,5,6 \text { at } 100 \mu \mathrm{M}\end{array}$ & $\begin{array}{l}{ }^{8} \mathrm{IP}_{3} \text { receptor antagonist at } 30-100 \mu \mathrm{M} \\
{ }^{9} \text { Inhibits SERCA at } 10-100 \mu \mathrm{M} \\
{ }_{11} \\
\left.{ }^{10} \text { Inhibits TRPV } 6 \text { at } 100 \mu \mathrm{M} \&{ }^{11} \text { Inhibits TRPM2 (at } 10-100 \mu \mathrm{M}\right) \\
{ }^{12} \text { Bctivates TRPV1, V2 \& V3 at } \sim 0.01-5 \mathrm{mM} \text {. } \\
{ }_{\text {B }} \text {. }\end{array}$ & $\begin{array}{l}5,6 \text { DeHaven et al., } 2008 \\
{ }^{3} \text { Bomben and Sontheimer } 2008 \\
{ }^{8} \text { Maruyama et al., 1997; Missiaen et al., } 2001 \\
{ }^{9} \text { Bilmen et al., } 2002 \\
{ }^{10} \text { Kovacs et al., } 2012 \\
{ }^{11} \text { Togashi et al., } 2008 \\
{ }^{12} \text { Hu et al., 2004 } \\
{ }^{13} \text { Bai et al., 2006; Yang et al., } 2011\end{array}$ \\
\hline $\begin{array}{l}\text { SKF } 96365 \\
(3 \mu \mathrm{M})\end{array}$ & $\begin{array}{l}{ }^{14} \text { Inhibits STIM1 at } 20 \mu \mathrm{M} \\
{ }^{15} \text { Inhibits TRPC } 1,3,5,6 \text { at } 25 \mu \mathrm{M}\end{array}$ & $\begin{array}{l}{ }^{16} \mathrm{Blocks} \text { low voltage-activated T-type } \mathrm{Ca}^{2+} \text { channels at } 1-10 \mu \mathrm{M} \\
{ }^{17} \mathrm{Blocks} \mathrm{K}^{+} \text {channels at } 200 \mu \mathrm{M}\end{array}$ & $\begin{array}{l}{ }^{14} \text { Liou et al., } 2005 \\
{ }^{15} \text { Bomben and Sontheimer 2008; Song et al., } 2014 \\
{ }^{16} \text { Singh et al., } 2010 \\
{ }^{17} \text { Schwarz et al., } 1994\end{array}$ \\
\hline
\end{tabular}


embryo, especially from the yolk cell (Fig. 5A). This resulted in a mean $\left[\mathrm{Ca}^{2+}\right]$ of $\sim 0.55 \mathrm{nM}$ near to the embryo, when compared with a mean $\left[\mathrm{Ca}^{2+}\right]$ of less than $0.05 \mathrm{nM}$ when the microelectrode was moved to a reference position in another part of the dish. These data indicate that even when care is taken to attempt to ensure $\mathrm{Ca}^{2+}$-free conditions, embryos will leak small amounts of $\mathrm{Ca}^{2+}$ into their immediate micro-environment and thus are never developing in a truly $\mathrm{Ca}^{2+}$-free medium.

We subsequently investigated the $\mathrm{Ca}^{2+}$ fluxes generated in different regions of the cleavage furrow in embryos bathed in normal Danieau's solution (i.e. containing, $0.18 \mathrm{mM} \mathrm{Ca}^{2+}$; Fig. $5 \mathrm{C}$,D). While a small efflux of $\mathrm{Ca}^{2+}$ occurred at the localised base of the cleavage furrow (position 0 in Fig. 5 C,D), a distinct influx of $\mathrm{Ca}^{2+}$ was observed in the sides of the deepening furrow (positions 1 and 2 in Fig. 5 C,D). These results indicate that SOCE may indeed occur during cleavage furrow deepening during the early division cycles in embryos developing in $\mathrm{Ca}^{2+}$-containing medium. Furthermore, our immunolabeling data (Fig. 6) showed that one component of SOCE, TRPC1 (Ambudkar et al., 2007), was also localised the sides of the deepening cleavage furrow (i.e., in the same location where the distinct $\mathrm{Ca}^{2+}$ influx was recorded) but not at the base of the furrow (i.e., where the small $\mathrm{Ca}^{2+}$ efflux was recorded). Thus, the data obtained from our $\mathrm{Ca}^{2+}$ flux and TRPC1 immunolabeling experiments substantiate those from our inhibitor experiments, which suggest that SOCE does play a role in the furrow deepening and apposition stages of cytokinesis during the early cell division cycles of zebrafish embryos when the cell size is comparatively large, when compared with small somatic cells.

In summary, we report that in the large, meroblastically cleaving eggs of zebrafish, SOCE does not appear to be required for mitosis, furrow positioning, or furrow propagation (where $\mathrm{Ca}^{2+}$ stored in the ER seems to be adequate for generating the required intracellular signals), but it does appear to be essential for sustaining elevated levels of $\left[\mathrm{Ca}^{2+}\right]_{\mathrm{i}}$ for the extended time periods that are required during furrow deepening and subsequent daughter cell apposition of large embryonic cells. Details of our new findings are summarized schematically in Figure 7.

\section{Materials and Methods}

\section{Embryo collection}

Wild-type (AB strain) zebrafish (Danio rerio) were maintained on a 14hour light/10-hour dark cycle to stimulate spawning (Westerfield, 1994). Fertilized eggs were collected within $\sim 5$ min of spawning, as described previously (Webb etal., 1997). To enhance the optical clarity during imaging, embryos were dechorionated by treatment with protease (Sigma-Aldrich, St. Louis, MO, USA) at $1 \mathrm{mg} / \mathrm{ml}$ in Danieau's solution (17.4 $\mathrm{mM} \mathrm{NaCl}, 0.21$ $\mathrm{mM} \mathrm{KCl}, 0.18 \mathrm{mM} \mathrm{Ca}\left(\mathrm{NO}_{3}\right)_{2}, 0.12 \mathrm{mM} \mathrm{MgSO} \cdot 7 \mathrm{H}_{2} \mathrm{O}, 1.5 \mathrm{mM}$ HEPES, $\mathrm{pH}$ 7.2), as described previously (Webb and Miller, 2013). Embryos were also maintained in Danieau's solution at $\sim 28.5^{\circ} \mathrm{C}$ during the course of all experiments.

\section{Drug treatment}

A stock solution of $100 \mathrm{mM}$ SKF 96365 hydrochloride (Calbiochem, Billerica, MA, USA) was prepared in Milli-Q water, whereas stock solutions of $30 \mathrm{mM}$ 2-aminoethoxydiphenyl borate (2-APB; Sigma-Aldrich), $100 \mathrm{mM}$ BTP-2 (also called YM58483; Tocris Bioscience, Bristol, UK), 10 mM ML 218 hydrochloride (Tocris Bioscience) and $40 \mathrm{mM}$ trans-Ned-19 (Enzo Life Sciences, Inc., Farmingdale, NY, USA) were prepared in DMSO. Zebrafish embryos were first dechorionated using protease. They were then transferred to an imaging chamber and incubated in Danieau's solution containing 3 $\mu \mathrm{M}$ ML 218 hydrochloride, $20 \mu \mathrm{M}$ BTP-2, $100 \mu \mathrm{M}$ trans-Ned-19, $10 \mu \mathrm{M}$ 2-APB or $3 \mu \mathrm{M}$ SKF 96365 hydrochloride starting from the 1-cell stage. Embryos were incubated in the drugs throughout the duration of experiments. As controls, embryos were either incubated in Danieau's solution alone or were treated with Danieau's solution containing $1 \%$ DMSO starting at the 1-cell stage.

\section{SYTOX green labelling and image acquisition}

Newly fertilized embryos were immobilised in small grooves made in $1 \%$ agarose in the microwells of P35G-1.5-14-C glass-bottom culture dishes (MatTek, Ashland, MA, USA). These chambers were used for both microinjection and imaging as embryos could be oriented with a pair of watchmaker's forceps and held in the desired position. SYTOX Green (Molecular Probes, Life Technologies, Carlsbad, CA, USA) was provided as a stock solution of $5 \mathrm{mM}$ in DMSO and diluted to $10 \mu \mathrm{M}$ (also with DMSO) just prior to use. Embryos were injected with $\sim 2.28 \mathrm{nl}$ SYTOX Green at the 1-cell stage. Details regarding the microinjection methods used are described in detail by Webb et al., (2013). Embryos were then manually dechorionated using watchmaker's forceps and transferred back to the microinjection/imaging chamber for subsequent image acquisition. Embryos were untreated or were treated with $3 \mu \mathrm{M}$ SKF 96365 hydrochloride up to the time that the untreated controls reached the 64-cell stage (i.e., $\sim 2$ hpf) for this experiment.

\section{Bright-field and fluorescence image acquisition}

Bright-field and fluorescence images were acquired using a Nikon Ds-5Mc CCD camera mounted on a Nikon AZ100 microscope using an AZ Plan Apo 4X lens. SYTOX Green fluorescence images were acquired using $460-500 \mathrm{~nm}$ excitation and $510-560 \mathrm{~nm}$ emission.

\section{Aequorin-based microinjection and $\mathrm{Ca}^{2+}$ imaging}

Embryos at the 1-cell stage were injected with approximately $2 \mathrm{nl}$ of $f$-aequorin (supplied by Dr Osamu Shimomura, the Photoprotein Laboratory, Falmouth, MA, USA; at $\sim 0.5-1 \%$ in $100 \mathrm{mM} \mathrm{KCl}, 5 \mathrm{mM}$ MOPS, $50 \mu \mathrm{M}$ EDTA) into the top of the yolk. In this way, $f$-aequorin was carried into the forming blastodisc by ooplasmic streaming (Leung et al., 1998). Aequoringenerated luminescence images and bright-field images were collected with our electron multiplying charge coupled device (EMCCD; Andor, Belfast, Northern Ireland, UK) based photon imaging microscope (PIM) system (custom-made by Science Wares, Falmouth, MA, USA; Miller et al., 1994; Webb et al., 2010), using a Zeiss FLUAR 20x/0.75 N.A. objective lens. $\mathrm{Ca}^{2+}$ signalling information and bright-field images were acquired from embryos incubated in DMSO (control), $10 \mu \mathrm{M}$ 2-APB or $3 \mu \mathrm{M}$ SKF 96365 during the first cell division cycle. The imaging data were subsequently analysed with the Photon Viewer 2 review software (Science Wares).

\section{Scanning $\mathrm{Ca}^{2+}$ ion-selective electrode measurements}

The scanning ion-selective electrode technique (SIET; Kühtreiber and Jaffe, 1990; Marenzana et al., 2005) was used to measure the $\mathrm{Ca}^{2+}$ flux and the local $\left[\mathrm{Ca}^{2+}\right]$ around embryos. Glass micropipettes were pulled from TW150-4 glass capillaries with an outer diameter of $1.5 \mathrm{~mm}$ (World Precision Instruments, Sarasota, FL, USA) using a P-97 Flaming/Brown pipette puller (Sutter instruments, San Rafael, CA, USA). Typical ion-selective microelectrodes (ISM) with a tip diameter of 2-3 $\mu \mathrm{m}$ were silanized first by heating to $100^{\circ} \mathrm{C}$ overnight on a Teflon holder (Science Wares, East Falmouth, MA, USA) and then by coating the inner surface with $\mathrm{N}, \mathrm{N}-$ dimethyltrimethylsilylamine (Sigma Aldrich, St Louis, MO, USA) at $200^{\circ} \mathrm{C}$ for at least $45 \mathrm{~min}$. When making $\mathrm{Ca}^{2+}$ flux measurements, an ISM was back-filled with $100 \mathrm{mM} \mathrm{CaCl}$, solution (as the electrolyte) to a column length of $\sim 1 \mathrm{~cm}$ and then front-filled with $\mathrm{Ca}^{2+}$ ionophore 1 cocktail A (Fluka Analytical, Sigma Aldrich, St Louis, MO, USA) to a column length of $\sim 25$ $\mu \mathrm{m}$, after which it was connected to an IPA-2 ion polarographic amplifier (Applicable Electronics LLC, New Haven, CT, USA) with a piece of Ag/ $\mathrm{AgCl}$ wire. A reference electrode (Ml-402; Microelectrodes, Inc. Bedford, $\mathrm{NH}$, USA) was used to connect the bath medium with the IPA-2 amplifier to 
complete the circuit. The SIET system was assembled on an Axiovert 100 inverted microscope (Carl Zeiss AG, Oberkochen, Germany) on a vibration isolation table (Technical Manufacturing Corporation, Peabody, MA, USA). The system was shielded from electromagnetic interference with a stainless steel Faraday Cage (Applicable Electronics LLC), in which the internal temperature was maintained with a temperature controller connected to a fan heater made in the HKUST mechanical workshop. The position and speed of oscillation of the ISM were controlled with 3D stepper motors mounted on the microscope stage, which were operated remotely using the custom-designed Automated Scanning Electrode Technique (ASET) software (Science Wares Inc., East Falmouth, MA, USA). This software was also used for data acquisition and image capture. Before each experiment, a freshly prepared ISM was calibrated against three concentrations of $\mathrm{Ca}^{2+}$ (i.e., $0.1 \mathrm{mM}, 1 \mathrm{mM}$, and $10 \mathrm{mM}$ ) to calculate the Nernstian slope of the ISM via the ASET software. For a divalent cation such as $\mathrm{Ca}^{2+}$, an ISM was considered to be acceptable for use if it yielded a voltage change of $\sim 29 \pm 3 \mathrm{mV}$ per 10 -fold change of $\left[\mathrm{Ca}^{2+}\right]$.

\section{Measuring $\mathrm{Ca}^{2+}$ fluxes around embryos bathed in ' $\mathrm{Ca}^{2+}$-free' Danieau's solution}

In some experiments, $\mathrm{Ca}^{2+}$ fluxes were measured around embryos bathed in so-called 'C $\mathrm{Ca}^{2+}$-free' Danieau's solution (Webb et al., 1997). Thus, when preparing the Danieau's solution, $\mathrm{Ca}\left(\mathrm{NO}_{3}\right)_{2}$ was omitted and $0.3 \mathrm{mM}$ EGTA (Sigma Aldrich, St Louis, MO, USA) was added, as described by Webb et al., (1997). Newly fertilized embryos were dechorionated and immobilized in shallow wells made in $1 \%$ agarose in normal (i.e., containing $\mathrm{Ca}^{2+}$ ) Danieau's solution in a 35-mm tissue culture plate (Becton Dickinson Labware, Franklin Lakes, NJ, USA). In these experiments, a single dechorionated embryo was put in a separate $\mathrm{Ca}^{2+}$-free imaging chamber, as described previously (Webb et al., 1997). Once the SIET system was calibrated, four points were scanned around the yolk and four points were scanned at various positions across the dividing blastodisc, with each scan lasting for $\sim 2 \mathrm{~min}$. Sampling involved a move-wait-measure procedure where the ISM was oscillated over a period of $\sim 5.52 \mathrm{~s}$ between the origin (i.e., at a distance of $\sim 2-5 \mu \mathrm{m}$ from the sample) and a position some 10 to $20 \mu \mathrm{m}$ away from the sample. The ISM was vibrated orthogonally to the surface of the embryo and the microvolt difference between the paired points of vibration extremities was used to calculate the flux rate (in pmol cm $\mathrm{s}^{-1}$ ).

\section{Measuring $\mathrm{Ca}^{2+}$ fluxes along the cleavage furrow in normally devel- oping embryos}

In another series of experiments, $\mathrm{Ca}^{2+}$ fluxes were measured at various points across the cleavage furrow of embryos bathed in normal Danieau's solution during cytokinesis of the first few cell division cycles. Thus, following calibration of the SIET system, five points were scanned along the cleavage furrow during deepening, and again each scan lasted for $\sim 2$ min.

\section{Immunocytochemistry}

Dechorionated embryos were fixed at $\sim 47 \mathrm{mpf}$ (i.e., during furrow deepening of the first cell division cycle) with $4 \%$ paraformaldehyde and $4 \%$ sucrose in PBS (pH 7.3; Westerfield, 1994) overnight at $4^{\circ} \mathrm{C}$, after which they were washed thoroughly with PBS. They were washed for 1 $\mathrm{h}$ with PBS containing $0.1 \%$ tween-20 (PBST) and then incubated with PBST containing $1 \%$ DMSO (PBSTD) for one hour in the dark at room temperature, after which they were incubated with blocking buffer (PBSTD containing $10 \%$ goat serum and 1\% BSA) at room temperature for $2 \mathrm{hrs}$.

Embryos were then incubated with the anti-TRPC1 antibody (Thermo Fisher Scientific Inc., Rockford, IL, USA; at a dilution of 1:200 in blocking buffer) overnight at $4^{\circ} \mathrm{C}$. They were then washed extensively with PBSTD containing $1 \%$ goat serum (PBSTD-serum), and incubated with an Alexa Fluor 488-conjugated goat anti-rabbit lgG (Life Technologies, Thermo Fisher Scientific Inc.) diluted 1:200 in blocking buffer for 3 hrs at room temperature, after which they were washed extensively again with PBSTD-serum in the dark. The embryos were then labelled with Alexa Fluor 568-tagged phalloidin (Life Technologies, Thermo Fisher Scientific Inc.) at 1:50 in blocking buffer and incubated overnight at $4^{\circ} \mathrm{C}$ in the dark, after which they were washed with PBSTD, then PBST and finally PBS prior to visualization via confocal microscopy. Confocal images were acquired using a Nikon C1 laser scanning confocal system mounted on an Eclipse 90i microscope using a Nikon Fluor 20x/0.5 NA water immersion lens. Green fluorescence was captured using a $488 \mathrm{~nm}$ excitation wavelength and a 515/530 nm emission filter, while red fluorescence was captured using $543 \mathrm{~nm}$ excitation and a $570 \mathrm{~nm}$ long-pass emission filter.

\section{Data analysis and figure preparation}

Numerical data were exported to Microsoft Office Excel 2010 (Microsoft, Redmond, WA, USA) for statistical analyses and graph plotting. Images were analysed and distances measured using ImageJ (National Institutes of Health, Bethesda, MD, USA), and figures were prepared using Corel Graphics X5 (Corel, Ottawa, ON, Canada).

\section{Acknowledgements}

This work was funded by the Hong Kong Research Grants Council General Research Fund awards HKUST662211, 662113, and 16101714, an ANR/RGC joint research scheme grant A-HKUST601/13; and the Hong Kong Theme-based Research Scheme award T13-706/11-1. We thank Prof Greg Barritt (University of Flinders, Australia) for his useful comments regarding the pharmacological agents utilized in this project. We also thank Mr Chris Shipley (Applicable Electronics LLC, New Haven, CT, USA) and Mr Eric Karplus (Science Wares Inc., Falmouth, MA, USA) for providing us with the scanning ion-selective microelectrode equipment and ASET software, respectively.

\section{References}

AMBUDKAR IS, ONG HL, LIU X, BANDYOPADHYAY B and CHENG KT (2007). TRPC1: The link between functionally distinct store-operated calcium channels. Cell Calc 42: 213-223.

BAI D, DEL CORSSO C, SRINIVAS M and SPRAY DC (2006). Block of specific gap junction channel subtypes by 2-aminoethyoxydiphenyl borate (2-APB). $J$ Pharmacol Exp Ther 319: 1452-1458.

BERRIDGE MJ, LIPP P and BOOTMAN M (2000). The versatility and universality of calcium signalling. Nature Rev Mol Cell Biol 1: 11-21.

BILMEN JG, WOOTTON LL, GODFREY RE, SMART OSA and MICHELANGELI $F$ (2002). Inhibition of SERCA Ca ${ }^{2+}$ pumps by 2-aminoethyoxydiphenyl borate (2-APB). 2-APB reduces both $\mathrm{Ca}^{2+}$ binding and phosphoryl transfer from ATP, by interfering with the pathway leading to the $\mathrm{Ca}^{2+}$ binding sites. Eur $\mathrm{J}$ Biochem 269: 3678-3687.

BOMBEN VC and SONTHEIMER HW (2008). Inhibition of transient receptor potential canonical channels impairs cytokinesis in human malignant gliomas. Cell Prolif 41: 98-121.

CHAN C, HARLAND ML, WEBB SE, MILLER AL and BARRITT GJ (2003). Evidence that $\mathrm{Ca}^{2+}$ inflow through liver cell store-operated $\mathrm{Ca}^{2+}$ channels does not require the thapsigargin-sensitive endoplasmic reticulum $\left(\mathrm{Ca}^{2+}+\mathrm{Mg}^{2+}\right)$ ATP-ase. Cell Calcium 35: 317-331.

CHANG DC and MENG C (1995). A localized elevation of cytosolic free calcium is associated with cytokinesis in the zebrafish embryo. J Cell Biol 131: 1539-1545.

CHANG DC and LU P (2000). Multiple types of calcium signals are associated with cell division in the zebrafish embryo. Microsc Res Tech 49: 111-122.

CRÉTON R, SPEKSNIJDER JE and JAFFE LF (1998). Patterns of free calcium in zebrafish embryos. J Cell Sci 111: 1613-1622.

DANILCHIK MV, FUNK, WC, BROWN EE and LARKIN K (1998). Requirement for microtubules in new membrane formation during cytokinesis of Xenopus embryos. Dev Biol 194: 47-60.

DAVISLC, MORGANAJ, CHENJL, SNEAD CM, BLOOR-YOUNGD, SHENDEROVE, STANTON-HUMPHREYS MN, CONWAY SJ, CHURCHILLGC, PARRINGTON J, CERUNDOLO V and GALIONEA (2012). NAADP activates two-pore channels on Tcell cytolytic granules to stimulate exocytosis and killing. Curr Biol22: 2331-2337.

DEHAVEN WI, SMYTH JT, BOYLES RR, BIRD GS and PUTNEY JW JR (2008). Complex actions of 2-aminoethyldiphenyl borate on store-operated calcium entry. 
J Biol Chem 283: 19265-19273.

DERLERI, SCHINDLR, FRITSCHR, HEFTBERGERP, RIEDLMC, BEGGM, HOUSE D AND ROMANIN C (2013). The action of selective CRAC channel blockers is affected by the Orai pore geometry. Cell Calcium 53: 139-151.

FLUCK RA, MILLER AL and JAFFE LF (1991). Slow calcium waves accompany cytokinesis in medaka fish eggs. J Cell Biol 115: 1259-1265.

GRIGORIEVI, GOUVEIA SM, VAN DER VAART B, DEMMERS J, SMYTH JT, HONNAPPA S, SPLINTER D, STEINMETZ MO, PUTNEY JW, HOOGENRAAD CC and AKHMANOVA A (2008). STIM1 is a MT-plus-end-tracking protein involved in remodeling of the ER. Curr Biol 18: 177-182.

GUERRERO-HERNANDEZA, LEON-APARICIO D, CHAVEZ-REYES J, OLIVARESREYES JA and DEJESUS S (2014). Endoplasmic reticulum stress in insulin resistance and diabetes. Cell Calcium 56: 311-322.

HE LP, HEWAVITHARANA T, SOBOLOFF J, SPASSOVA MA and GILL DL (2005). A functional link between store-operated and TRPC channels revealed by the 3,5-bis(trifluoromethyl)pyrazole derivative, BTP2. J Biol Chem 280: 10997-11006.

HEWAVITHARANA T, DENG X, SOBOLOFF J and GILL DL (2007). Role of STIM and Orai proteins in the store-operated calcium signaling pathway. Cell Calcium 42: 173-182.

HU HZ, GU Q, WANG C, COLTON CK, TANG J, KINOSHITA-KAWADA M, LEE LY, WOODS JD and ZHU MX (2004). 2-Aminoethoxydiphenyl borate is a common activator of TRPV1, TRPV2, and TRPV3. J Biol Chem 279: 35741-35748.

JESUTHASAN S (1998). Furrow-associated microtubule arrays are required for the cohesion of zebrafish blastomeres following cytokinesis. J Cell Biol 111: 3695-3703.

KOVACS G, MONTALBETTI N, SIMONIN A, DANKO T, BALAZS B, ZSEMBERY A and HEDIGER MA (2012). Inhibition of the human epithelial calcium channel TRPV6 by 2-aminoethoxyldiphenyl borate (2-APB). Cell Calcium 52: 468-480.

KÜHTREIBER WM and JAFFE LF (1990). Detection of extracellular calcium gradients with a calcium-specific vibrating electrode. J Cell Biol 110: 1565-1573.

LEE KW, WEBB SE and MILLER AL (2003). $\mathrm{Ca}^{2+}$, released via IP ${ }_{3}-\mathrm{R}$, is required for furrow deepening during cytokinesis in zebrafish embryos. IntJDev Bio/47:411-421.

LEE KW, HO SM, WONG CH, WEBB SE and MILLER AL (2004). Characterization of mid-spindle microtubules during furrow positioning in early cleavage period zebrafish embryos. Zygote 12: 221-230.

LEE KW, WEBB SE and MILLER AL (2006). Requirement for a localized, IP $R$ generated $\mathrm{Ca}^{2+}$ transient during the furrow positioning process in zebrafish zygotes. Zygote 14: 143-155.

LEUNG CF, WEBB SE and MILLER AL (1998). Calcium transients accompany ooplasmic segregation in zebrafish embryos. Dev Growth Differ 40: 313-326.

LI C-J, HEIM R, LU P, TSIEN RY and CHANG DC (1999). Dynamic redistribution of calmodulin in HeLa cells during cell division as revealed by a GFP-calmodulin fusion protein technique. J Cell Sci 112: 1567-1577.

LI H, DING X, LOPEZ JR, TAKESHIMA H, MA J, ALLEN PD and ELTIT JM (2010). Impaired Orai1-mediated resting $\mathrm{Ca}^{2+}$ entry reduces the cytosolic $\left[\mathrm{Ca}^{2+}\right]$ and sarcoplasmic reticulum $\mathrm{Ca}^{2+}$ loading in quiescent junctophilin 1 knock-out myotubes. J Biol Chem 285: 39171-39179.

LI WM, WEBB SE, CHAN CM and MILLER AL (2008). Multiple roles of the furrow deepening $\mathrm{Ca}^{2+}$ transient during cytokinesis in zebrafish embryos. Dev Biol 316 : 228-248

LI WM, LEE KW, WEBB SE and MILLER AL (2006). The role of localized $\mathrm{Ca}^{2+}$ transients in SNARE-mediated vesicle transport and exocytosis during ingression and zipping of cleavage furrows during cytokinesis in zebrafish embryos. Exp Cell Res 312: 3260-3275.

LIOU J, KIM ML, HEO WD, JONES JT, MYERS JW, FERRELL JR JE and MEYER $\mathrm{T}$ (2005). STIM is a Ca ${ }^{2+}$ sensor essential for $\mathrm{Ca}^{2+}$-store-depletion-triggered $\mathrm{Ca}^{2+}$ influx. Curr Biol 15: 1235-1241.

MARENZANA M, SHIPLEY AM, SQUITIERO P, KUNKEL JG and RUBINACCI A (2005). Bone as an ion exchange organ: Evidence for instantaneous cell-dependent calcium efflux from bone not due to resorption. Bone 37: 545-554.

MARUYAMA, T, KANAJI T, NAKADE S, KANNO T and MIKOSHIBA K (1997). 2-APB, 2-aminoethoxydiphenyl borate, a membrane-permeable modulator of $\operatorname{Ins}(1,4,5)$ P-3-induced $\mathrm{Ca}^{2+}$ release. Biochem J 122: 498-505.

MILLER AL, KARPLUS E and JAFFE LF (1994). Imaging $\left[\mathrm{Ca}^{2+}\right]_{i}$ with aequorin using a photon imaging detector. In A Practical Guide to the Study of Calcium in Living Cells (Ed R. Nuccitelli). Methods in Cell Biology, Vol. 40, Academic Press Inc.,
San Diego, pp. 305-338.

MISSIAEN L, CALLEWAERT G, DE SMEDT H and PARYS J (2001). 2-Aminoethoxydiphenyl borate affects the inositol 1,4,5-trisphosphate receptor, the intracellular $\mathrm{Ca}^{2+}$ pump and then non-specific leak from the non-mitochondrial $\mathrm{Ca}^{2+}$ stores in permeabilised A7r5 cells. Cell Calcium 29: 111-116.

NAYLOR E, ARREDOUANI A, VASUDEVAN SR, LEWIS AM, PARKESH R, MIZOTE A, ROSE D, THOMAS JM, IZUMI M, GANESAN A, GALIONE A and CHURCHILL GC (2009). Identification of a chemical probe for NAADP by virtual screening. Nat Chem Biol 5: 220-226.

NG LC, O'NEILL KG, FRENCH D, AIREY JA, SINGER CA, TIAN H, SHEN XM and HUME JR (2012). TRPC1 and Orai1 interact with STIM1 and mediate capacitative $\mathrm{Ca}^{2+}$ entry caused by acute hypoxia in mouse pulmonary arterial smooth muscle cells. Am J Physiol Cell Physiol 303: C1156-C1172.

PAREKH AB and PUTNEY JW (2005). Store-operated calcium channels. Physiol Rev 85: 757-810.

PRESTON SF, SHA'AFI RI and BERLIN RD (1991). Regulation of $\mathrm{Ca}^{2+}$ influx during mitosis: $\mathrm{Ca}^{2+}$ influx and depletion of intracellular $\mathrm{Ca}^{2+}$ stores are coupled in interphase but not mitosis. Cell Regul 2: 915-925.

SCHARZ G, DROOGMANS G and NILIUS B (1994). Multiple effects of SK\&F 96365 on ionic currents and intracellular calcium in human endothelial cells. Cell Calcium 15: 45-54.

SINGH A, HILDEBRAND ME, GARCIA E and SNUTCH TP (2010). The transient receptor potential channel antagonist SKF96365 is a potent blocker of low-voltageactivated T-type calcium channels. Br J Pharmacol 160: 1464-1475.

SMYTH JT, DEHAVEN WI, BIRD GS and PUTNEY JW (2007). Role of the microtubule cytoskeleton in the function of the store operated $\mathrm{Ca}^{2+}$ channel activator STIM1. J Cell Sci 120: 110-122.

SMYTH JT and PUTNEY JW (2012). Regulation of store-operated calcium entry during cell division. Biochem Soc Trans 40: 119-123.

SONG M, CHEN D and YU SP (2014). The TRPC channel blocker SKF 96365 inhibits glioblastoma cell growth by enhancing reverse mode of the $\mathrm{Na}^{+} / \mathrm{Ca}^{2+}$ exchanger and increasing intracellular $\mathrm{Ca}^{2+}$. Br J Pharmacol 171: 3432-3437.

TAKAYAMA M, NOGUCHI T, YAMASHIRO S and MABUCHI I (2002). Microtubule organization in the Xenopus egg during the first cleavage and its role in cytokinesis. Cell Struct Funct 27: 163-171.

TAKEZAWA R, CHENG H, BECK A, ISHIKAWA J, LAUNAY P, KUBOTA H, KINET JP, FLEIG A, YAMADA T and PENNER R (2006). A pyrazole derivative potently inhibits lymphocyte $\mathrm{Ca}^{2+}$ influx and cytokine production by facilitating transient receptor potential melastatin 4 channel activity. Mol Pharmacol 69: 1413-1420.

TANI D, MONTEILH-ZOLLER MK, FLEIG A and PENNER R (2007). Cell cycledependent regulation of store-operated $\mathrm{I}_{\mathrm{CBAC}}$ and $\mathrm{Mg}^{2+}$-nucleotide-regulated MagNuM (TRPM7) currents. Cell Calcium 41: 249-260.

TASAKA K, MIO M, FUJISAWA K and AOKI I (1991). Role of microtubules on $\mathrm{Ca}^{2+}$ release from the endoplasmic reticulum and associated histamine release from rat peritoneal mast cells. Biochem Pharmacol 41: 1031-1037.

TERASAKI K, CHEN LB and FUJIWARA K (1986). Microtubules and the endoplasmic reticulum are highly interdependent structures. J Cell Biol 103: 1557-1568.

TOGASHI K, INADA H and TOMINAGA M (2008). Inhibition of the transient receptor potential cation channel TRPM2 by 2-aminoethoxydiphenyl borate (2-APB). $\mathrm{Br}$ J Pharmacol 153: 1324-1330.

WATERMAN-STORER CM and SALMON ED (1998). Endoplasmic reticulum membrane tubules are distributed by microtubules in living cells using three distinct mechanisms. Curr Biol 8: 798-807.

WEBB SE, LEE KW, KARPLUS E and MILLER AL (1997). Localized calcium transients accompany furrow positioning, propagation, and deepening during the early cleavage period of zebrafish embryos. Dev Biol 192: 78-92.

WEBB SE and MILLER AL (2007). Ca ${ }^{2+}$ signaling during embryonic cytokinesis in animal systems. In: New Comprehensive Biochemistry Vol. 41: Calcium. A Matter of Life or Death. (Eds, J. Krebs, \& M. Michalak). Elsevier.

WEBB SE, LI WM and MILLER AL (2008). Calcium signaling during the cleavage period of zebrafish development. Phil Trans R Soc B 363: 1363-1369.

WEBB SE, ROGERS KL, KARPLUS E and MILLER AL (2010). The use of aequorins to record and visualize $\mathrm{Ca}^{2+}$ dynamics: from subcellular microdomains to whole organisms. In Calcium in Living Cells (Ed. M. Whitaker). Methods in Cell Biology, Vol. 99. Academic Press Inc., Burlington, pp. 263-300. 
WEBB SE, FLUCK RA and MILLER AL (2011). Calcium signaling during the early development of medaka and zebrafish. Biochimie 93: 2112-2125.

WEBB SE and MILLERAL (2013). Microinjecting holo-aequorin into dechorionated and intact zebrafish embryos. Cold Spring Harb Protoc 2013: 447-455. (doi:10.1101/ pdb.prot072967).

WEBB SE, GOULET C, CHAN CM, YUEN YF and MILLER AL (2013). Biphasic assembly of the contractile apparatus during the first two cell division cycles in zebrafish embryos. Zygote 22: 218-228.

WESTERFIELD M (1994). The Zebrafish Book. A guide for the laboratory use of zebrafish (Danio rerio), 2nd ed., University of Oregon Press, Eugene.

XIANGZ, THOMPSONAD, BROGANJT, SCHULTE ML, MELANCONBJ, MID, LEWIS LM, ZOU B, YANG L, MORRISON R, SANTOMANGO T, BYERS F, BREWER K,
ALDRICH JS, YU H, DAWSON ES, LI M, MCMANUS O, JONES CK, DANIELS JS, HOPKINS CR, XIE XS, CONN PJ, WEAVER CD and LINDSLEY CW (2011). The discovery and characterization of ML218: A novel, centrally active T-type calcium channel inhibitor with robust effects in STN neurons and in a rodent model of Parkinson's disease. ACS Chem Neurosci 2: 730-742.

YANG Y, CAO MH, WANG Q, YUAN DD, LI L and TAO $L$ (2011). The effects of 2-aminoethoxydiphenyl borate and diphenylboronic anhydride on gap junctions composed of Connexin43 in $\mathrm{TM}_{4}$ sertoli cells. Biol Pharm Bull 36: 1390-1397.

ZITT C, STRAUSS B, SCHWARZ EC, SPAETH N, RAST G, HATZELMANN A and HOTH M (2004). Potent inhibition of $\mathrm{Ca}^{2+}$ release-activated $\mathrm{Ca}^{2+}$ channels and T-lymphocyte activation by the pyrazole derivative BTP2. J Biol Chem 279: 12427-12437. 


\section{Further Related Reading, published previously in the Int. J. Dev. Biol.}

Egg activation in physiologically polyspermic newt eggs: involvement of IP3 receptor, PLCy, and microtubules in calcium wave induction

Tomoyo Ueno, Takehiro Ohgami, Yuichirou Harada, Shuichi Ueno and Yasuhiro Iwao

Int. J. Dev. Biol. (2014) 58: 315-323

Visualization, characterization and modulation of calcium signaling during the development of slow muscle cells in intact zebrafish embryos

Chris Y. Cheung, Sarah E. Webb, Donald R. Love and Andrew L. Miller

Int. J. Dev. Biol. (2011) 55: 153-174

Could modifications of signalling pathways activated after ICSI induce a potential risk of epigenetic defects?

Brigitte Ciapa and Christophe Arnoult

Int. J. Dev. Biol. (2011) 55: 143-152

Oscillatory $\mathrm{Ca} 2+$ dynamics and cell cycle resumption at fertilization in mammals: a modelling approach Geneviève Dupont, Elke Heytens and Luc Leybaert

Int. J. Dev. Biol. (2010) 54: 655-665

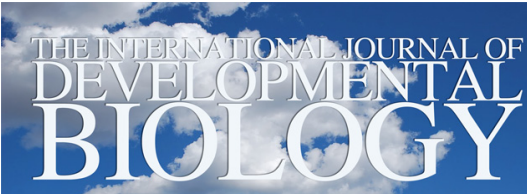

Volume 56 Nos. 10/11/12 - Special Issue
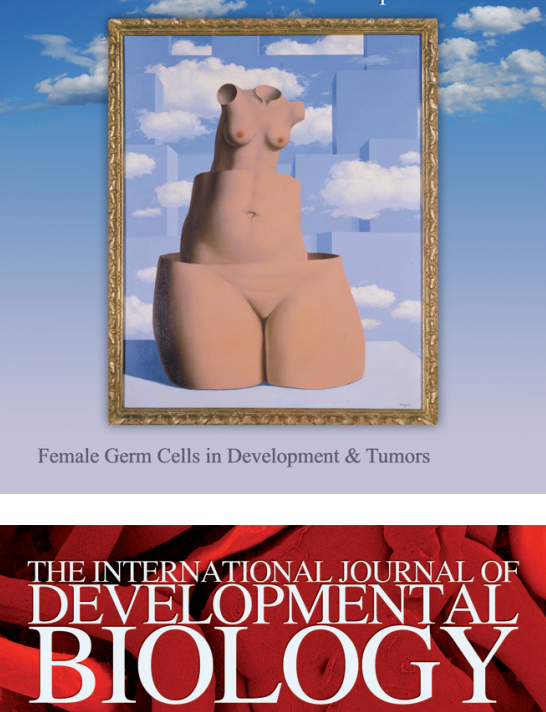

Volume 57 Nos. 2/3/4

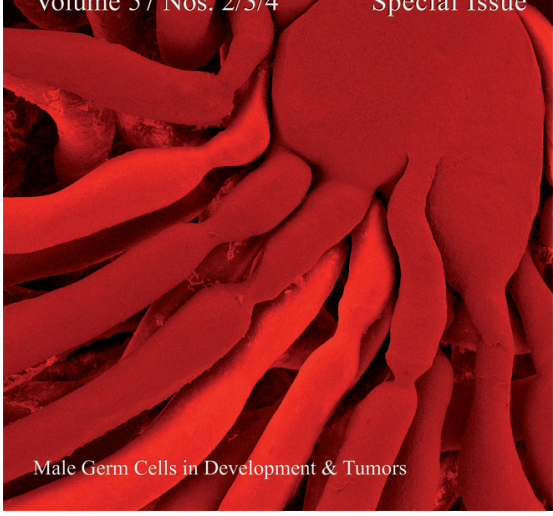

The role of ion fluxes in polarized cell growth and morphogenesis: the pollen tube as an experimental paradigm

Erwan Michard, Filipa Alves and José A. Feijó

Int. J. Dev. Biol. (2009) 53: 1609-1622

Sperm-activating peptides in the regulation of ion fluxes, signal transduction and motility

Alberto Darszon, Adán Guerrero, Blanca E. Galindo, Takuya Nishigaki and Christopher D. Wood

Int. J. Dev. Biol. (2008) 52: 595-606

The dynamics of calcium oscillations that activate mammalian eggs

Karl Swann and Yuansong Yu

Int. J. Dev. Biol. (2008) 52: 585-594

The choice between epidermal and neural fate: a matter of calcium. Marc Moreau and Catherine Leclerc Int. J. Dev. Biol. (2004) 48: 75-84
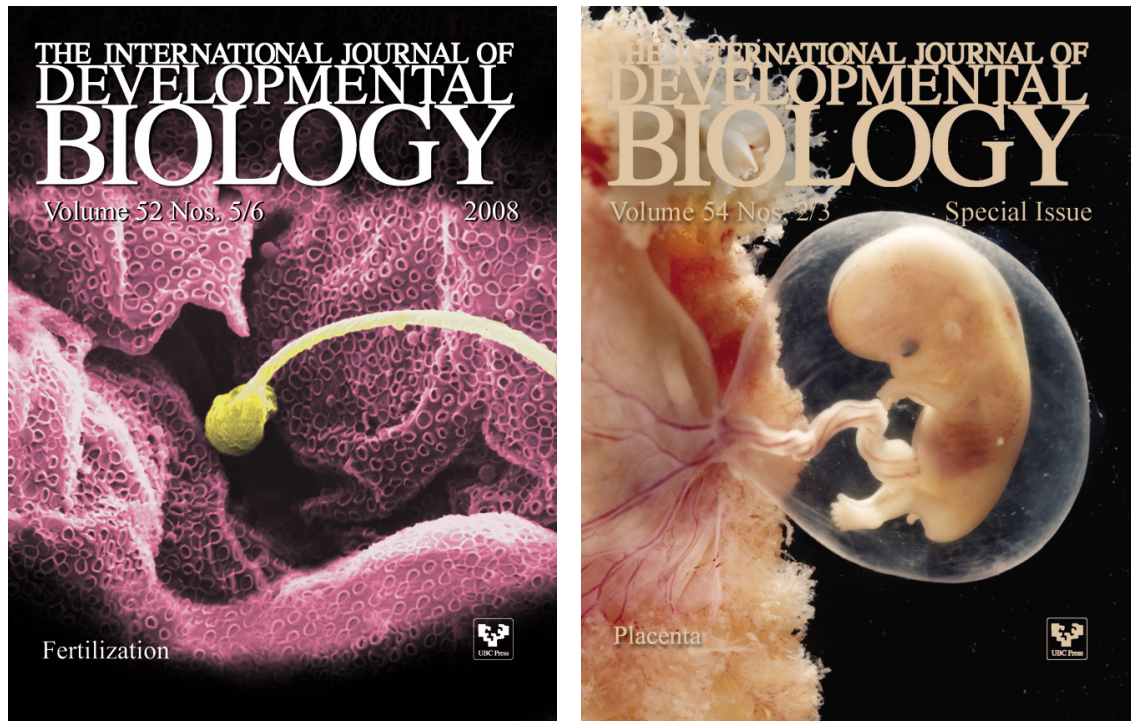